IZA DP No. 4698

Unequal Giving: Monetary Gifts to Children Across Countries and Over Time

Julie M. Zissimopoulos

James P. Smith

January 2010 


\title{
Unequal Giving: Monetary Gifts to Children Across Countries and Over Time
}

\author{
Julie M. Zissimopoulos
}

RAND

James P. Smith

RAND and IZA

Discussion Paper No. 4698

January 2010

IZA

P.O. Box 7240

53072 Bonn

Germany

Phone: +49-228-3894-0

Fax: +49-228-3894-180

E-mail: iza@iza.org

Any opinions expressed here are those of the author(s) and not those of IZA. Research published in this series may include views on policy, but the institute itself takes no institutional policy positions.

The Institute for the Study of Labor (IZA) in Bonn is a local and virtual international research center and a place of communication between science, politics and business. IZA is an independent nonprofit organization supported by Deutsche Post Foundation. The center is associated with the University of Bonn and offers a stimulating research environment through its international network, workshops and conferences, data service, project support, research visits and doctoral program. IZA engages in (i) original and internationally competitive research in all fields of labor economics, (ii) development of policy concepts, and (iii) dissemination of research results and concepts to the interested public.

IZA Discussion Papers often represent preliminary work and are circulated to encourage discussion. Citation of such a paper should account for its provisional character. A revised version may be available directly from the author. 
IZA Discussion Paper No. 4698

January 2010

\section{ABSTRACT \\ Unequal Giving: Monetary Gifts to Children Across Countries and Over Time*}

Money parents give their adult children may be important for the financing of a child's education or a first home, relaxing binding credit constraints or responding to a transitory income shock. Financial transfers however, may extend economic disparities across generations if the wealthy transfer considerable resources to their children while middle class and poor households do not. In this paper, we first examine annual gifts of money from parents to adult children in the United States and ten European countries using the 2004 waves of the Health and Retirement Study (HRS) and Survey of Health, Ageing and Retirement in Europe (SHARE). Second, utilizing the long panel of the HRS, we study the long-run behavior of parental monetary giving to children across families and within a family. We found that in all countries, some parents gave money to children, many did not, the amount was low, about 500 Euros annually per child, and varied by parental socio-economic status and public social expenditures. In the short term, parents in the U.S. gave money to a child to compensate for low earnings or satisfy an immediate need such as schooling. Over sixteen years, parents gave an average of about $\$ 38,000$ to all their children, five percent gave over $\$ 140,000$ and gave persistently. With time, the amount of money children in the same family received became more equal and a child's level of education was one of the few remaining sources of differences in money given to children. Overall, the annual amount of money parents gave adult children in any country was not enough to affect the distribution of resources within or between families in the next generation although the timing of transfers for schooling or housing may have a significant impact on an individual child. Annual parental transfers for college age children in school in the U.S. were substantially higher than average transfers to all children. The effect of parental transfers for higher education on intergenerational mobility in the U.S. will depend in part upon whether this financing is essential in the schooling decision.

JEL Classification: J10

Keywords: transfers

Corresponding author:

James P. Smith

RAND

1776 Main Street

P.O. Box 2138

Santa Monica, CA 90401-3208

USA

E-mail: smith@rand.org

\footnotetext{
* We thank Joanna Carroll, Patricia StClair and Sandy Chien for data file development and programming support. We are grateful for financial support from the NIA under grant R01AG024047.
} 


\section{Introduction}

Parents transfer an enormous amount of resources to their children when the children are living in the parental home. As adults, children may continue to receive direct monetary gifts and loans from their parents. Whatever its overall size, depending on when the monetary transfer occurs, monetary gifts may help children finance the purchase of a first home (Guiso and Jappelli, 2002), relax credit constraints (Cox and Jappelli, 1990) or finance higher education (Brown et al. 2006). Money given to an adult child may be in response to a transitory wealth or income shock. In addition, monetary gifts may be an important mechanism within families to equalize economic outcomes among children (Becker, 1981). Financial transfers by parents to adult children, however, may extend economic disparities across generations if high wealth families transfer wealth transfer considerable resources to their children while middle class and poor households do not.

Financial gifts to adult children by parents occur in the United States and much of Europe with about one-fifth to one-quarter of parents providing some money to children in a typical year. Even in countries with strong welfare states, parents provide monetary support to their adult children. How familial transfers respond to government programs that redistribute resources across generations will depend in part on why families give (transfer motives). For example, if family members are altruistically linked, their private transfers will undo government redistribution.

Moreover, in the United States, children within a family commonly receive unequal amounts of money from their parents while parents are alive but receive mostly equal amounts upon their parents' death (Hurd and Smith, 2002). There is considerable debate as to why intervivos giving and bequest patterns differ so much. This debate includes the nature of the unequal intervivos giving to children, with inconsistent results on whether or not children receiving transfers have lower socio-economic status than children not receiving transfers (McGarry and Schoeni, 1995 1997; Altonji et al 1997; Cox 1987). Finally, all of these empirically established patterns are based on single-period estimates and do not address the long-run magnitude and pattern of transfers.

In this paper, we first examine annual intervivos transfer of money from parents to children in the United States and ten Europe countries using the 2004 waves of the Health and Retirement Study (HRS) and Survey of Health, Ageing and Retirement in Europe (SHARE). The countries we study vary across many dimensions including the level of public expenditure on social programs. The effects of social programs on 
individuals and the distribution of wealth will depend upon the size and nature of private, familial transfers. Second, utilizing the long panel of the HRS, we calculate up to 16 years of inter-vivos financial transfers to children in the United States to study the long-run behavior of parental monetary giving to children across families and within a family. The long run magnitudes of parental monetary gifts to adult children and the persistence of giving over time shed light on their relevance for intergenerational transmission of wealth.

We found in all countries some parents gave money to children and many did not. The average annual amount of money parents gave all their children in 2004 was about 1,000 Euros in countries represented in SHARE (about 420 Euros per child) and just over 1800 Euros (about 580 Euros per child) in the United States. The distribution of amounts however, revealed a lot of heterogeneity. Five percent of U.S. parents gave about 9000 Euros or more annually to all children. Among the countries in SHARE, the top 5 percent gave 5000 Euros or more to children each year. The difference in the average amount given was explained in part by differences in parental socio-economic status and the variation in social public expenditures. The estimates of the amount of money parents gave children, however, were based on a single point in time and total wealth transfers to children through the mechanism of direct financial giving will depend in part on how persistent transfers are over time.

In the United States, over sixteen-years parents on average gave $\$ 37,765$ to all their children. Each child received $\$ 11,122$ while the child receiving in the top $5 \%$ of the distribution received $\$ 54,602$. The distribution of 16-year transfers was more equal than 2-year transfers across families. Moreover, over time children in the same family were more likely to receive the same amount, particularly children with high wealth parents, challenging the view that intervivos and bequest giving is fundamentally different.

Multivariate model results revealed that a short-term view of money given to children from parents would suggest giving was primarily compensatory (e.g. given to low earning children), or based on some immediate need (e.g for a new house or loss of a house, to finance education, for grandchildren). Over a longtime horizon however, a child's education was one of the few remaining sources of difference in money given to children. The timing and level of financial transfers to finance education (or housing) may have a significant impact on the welfare of a child and on intergenerational mobility if the financing is essential in the schooling decision. The magnitude of intervivos transfers over time however, is simply not large enough to affect the 
distribution of resources within or between families in the next generation. The remainder of this paper is divided into three sections. The following section describes data sources. The next section summarizes the main results and the final section offers conclusions and avenues for future research.

\section{Data Description}

Our research for the U.S. relies on longitudinal data from the Health and Retirement Study, a set of biennial surveys first fielded in 1992 and 1993 by the University of Michigan with the objective to monitor economic transitions in work, income, and wealth, as well as changes in many dimensions of health status among those over 50 years old. ${ }^{1}$ We use data from survey waves 1992, 1993, 1994, 1995, 1996 and biennial thereafter to $2006 .^{2}$ The measures of inter-vivos transfers are based on questions to respondents about financial help provided to children in the basic form "Including help with education but not shared housing or shared food (or any deed to a house), in the last two years did you or your spouse give financial help totaling $\$ 500$ or more to any of your children (or grandchildren)?" and including follow-on questions about the amount of money and to whom the money was given. ${ }^{3}$

Our research for Europe is based on the 2.3.0 release of the first wave (2004) of the Survey of Health, Ageing and Retirement in Europe (SHARE). ${ }^{4}$ Data from the first wave of SHARE are representative of the population of individuals age 50 and over from 11 European countries: Austria, Belgium, Denmark, France,

\footnotetext{
${ }^{1}$ The first survey, the Health and Retirement Study (HRS) began as a national sample of about 7,600 households (12,654 individuals) with at least one person in the birth cohorts of 1931 through 1941 (about 51-61 years old at the wave 1 interview in 1992). The second, the Assets and Health Dynamics of the Oldest Old (AHEAD), began in 1993 and included 6,052 households (8,222 individuals) with at least one person born in 1923 or earlier (70 or over in 1993). In 1998, HRS was augmented with baseline interviews from at least one household member from the birth cohort1924-1930 and 19421947 and was representative of all birth cohorts born in 1947 or earlier. In 2004, the HRS was again augmented with interviews from the birth cohort 1948-1953.

${ }^{2}$ For the original HRS respondents from survey wave 1992, we use a total of 8 waves of transfer data from 1992 to 2006 , which accounts for money given to children over 16 years. For the original AHEAD respondents from 1993, we have 7 waves of data for a total of 14 years of transfers. For respondents added in 1998, we have 5 survey waves from 1998 to 2006, or 10 years of transfer data, and for the most recent cohort added, the Early Baby Boomers, we have two waves of data from years 2004 and 2006 (4 years of transfer data).

${ }^{3}$ In the 1992 and 1994 survey waves of the original HRS respondents, the transfer questions varied slightly from the more recent waves. In 1992 financial help of $\$ 500$ or more over one year is asked about and in 1994, the threshold was $\$ 100$. To make transfers over waves comparable, we make the simplistic assumption that two-year transfer amounts are two times the annual giving amount in 1992 and censor to zero amounts less than \$500 for survey year 1994 .

${ }^{4}$ The SHARE data collection has been primarily funded by the European Commission. Additional funding came from the U.S. National Institute on Aging. Data collection for wave 1 was nationally funded in Austria, Belgium, France and Switzerland.
} 
Germany, Greece, Italy, the Netherlands, Spain, Sweden and Switzerland. ${ }^{5}$ SHARE was modeled on the HRS and designed for cross-national research such as this. In SHARE data, financial transfers from parents to children were measured over a 12 month period prior to the interview in the basic form "Not counting any shared housing or shared food, have you or your husband/wife/partner given any financial or material gifts to anyone inside or outside this household amounting to 250 euros or more?" and including follow-on questions about the amount of money and to whom the money was given for up to three children. ${ }^{6}$ Additionally, the interviewer was instructed to clarify the meaning of 'financial or material gift' as giving money or covering specific costs such as medical care, insurance, schooling, or down payment for a home and not to include loans.

The wording of the questions about money given from parents to children is similar across the two surveys but not exact. Respondents in the U.S. are asked to include loans while SHARE respondent are asked to exclude loans. For comparability across countries, we divide by two amounts given to children over a two-year period in the U.S. for an annual transfer amount. In addition, we use gifts of $\$ 500$ or more as the lower censor point. That is, we set to zero all amounts in the SHARE data below 407.68 euros (equal to $\$ 500$ in 2004 ).

\section{Results}

\section{Cross Country Variation in Annual Gifts of Money From Parents to All Children}

We examine the total sum of money parents give to all their children for all European countries represented in the first wave of SHARE (2004) with the exception of Switzerland because of the low response rate and for the U.S. from the 2004 wave of HRS. Table 1 shows the percent of parents giving to children, the mean amount parents give each year to all children the $90^{\text {th }}$ and $95^{\text {th }}$ percentiles, and the mean and median amounts parents give conditional on having given money to children for the 12 countries. A few households in Belgium report giving extremely high amounts so Table 1 also lists amounts based on observations censored above the $98^{\text {th }}$ percentile.

\footnotetext{
${ }^{5}$ Overall household response rate is 55.4\%. The response rate is lowest in Switzerland (37.4\%) and highest in France (69.4\%).

${ }^{6}$ Although only three transfers are reported this captures about 99 percent of all transfers. Only thirteen percent of households have four or more children with 96 percent of these household reporting two transfers or less. That is, only 115 households with four or more children use all available placeholders for reporting transfers and may possibly have made an additional transfer that was not recorded.
} 
Thirty-nine percent of parents give \$500 (408 Euros) or more to all their children in the U.S. over a twoyear period from 2002 to 2004 . We calculate an annual percent, taking into account the persistence of giving by some households, to be 25.2 percent, a higher fraction than the average of the SHARE countries (19.7 percent). ${ }^{7}$ Average amounts given to all children are higher in the U.S. (1,862 Euros) than in the countries represented in SHARE (1,012 Euros). Parents in SHARE countries that give to children give 5,127 Euros to children each year. Although this amount is higher than the conditional amount (4,795 Euros) given by parents in the U.S., it is primarily driven by a few high values and when outliers are excluded, the average amount given to all children, conditional on giving, is slightly higher in the U.S. than the countries of SHARE.

With the exception of Spain, the percentage of parents in the SHARE countries giving money to children is variable ranging between 16 percent (Italy) and 27 percent (Sweden). Only 8 percent of parents in Spain report giving money to children over a 12 month period although those parents that do give, give generously: on average about 5.5 thousand Euros. Only in Belgium do parents give on average more money (unconditional amounts) to their children than in the U.S. although trimming the top 2 percent of values reveals average amounts are highest in the U.S.. Conditional on giving, parents in three of the ten countries in Europe gave higher amounts of money to children (conditional, trimmed values, last column of Table 1) compared to the U.S.: Belgium, Denmark and France. Parents in the Netherlands and Greece give amounts to all children, conditional on giving, that are similar to parents in the U.S. (based on trimmed values).

Within countries, giving by parents across households is very unequal. For example, conditional mean amounts given are at least two times median amounts. Five percent of U.S. parents give about 9000 Euros or more annually to children (about 2800 Euros annually per child). Among the countries in SHARE, the top 5 percent give 5000 Euros or more to children annually (about 2100 Euros annually per child).

Observable differences across households will explain some of the variation in giving behavior within countries and across countries. Table 2 shows mean values of the characteristics of our sample of parents by country. Some notable difference across countries include a low rate of respondents with a college education in Italy and Spain (less than 10 percent) compared to about 20 percent or more in the other SHARE countries and

\footnotetext{
${ }^{7}$ Giving to children is persistent over time (Hurd, Smith, Zissimopoulos, 2008). The probability of giving over 2 years conditional on having given the previous 2 years is 0.30 . Under the assumption that biennial persistence approximates annual persistence then about 25.2 percent of parents give annually.
} 
the U.S.; a higher average number of children in the United States (3.22) than in the other European countries represented in the SHARE data (average across all is 2.4). On average, the countries of SHARE have lower income and wealth than the U.S. ${ }^{8}$ Household gross income in wave 1 is measured with error due to substantial non-response thus we also report in Table 1 average net income from wave 2 SHARE.

We next describe how money given to children varies with the age and wealth of the parent across country. To document mean age and wealth patterns in transfer amounts that are not primarily the result of high outlier amounts, we report values of money gifts to all children trimmed at the $98^{\text {th }}$ percentile. Figure 1 shows that in both the U.S. and in SHARE countries, the amount of money given to children declines with age. The amount given at ages 81 and older is half what is given at ages 50 to 55 in the European countries represented in SHARE. The decline is even more pronounced in the United States. Both age and cohort effects are present in these cross-sectional patterns although longitudinal analysis based on the HRS also reveals declining amounts of money with age (Hurd, Smith and Zissimopoulos, 2008). In all SHARE countries and in the U.S., the amount of money parents gave to all children increases with wealth. Parents in the top 25 percent of the wealth distribution give over 4 times as much to their children as those in the bottom quarter of the wealth distribution. In the U.S. the average amount of money given to all children among high wealth parents is almost 2,000 Euros annually compared to only 400 for low wealth parents. High wealth families across countries give vastly different amounts (Figure 2). High wealth parents in Belgium and Denmark give just under 1500 Euros annually while high wealth parents in Italy give only 400 Euros annually and in Spain they give only 162 Euros annually. Cultural values and social institutions, more generally, the strength of the welfare state may explain some of the cross-country differences in parental monetary transfers to adult children. The relationship between the welfare state and family transfers is inconclusive and depends on the motives for giving. On the one hand, services offered by the state may "crowd out” or substitute for giving by families if families are altruistically linked. For example, state financed higher education may crowd out financing of higher education by parents. On the other hand, families and institutions may complement each other by providing services and/or income simultaneously or the existence of public support may be neutral on parental giving.

${ }^{8}$ Income in SHARE wave 1 had substantial non-response. Although imputations were computed with a conditional hot deck for responses bracketed into income categories, there was also substantial non-response to the brackets thus the mean values reported here should be interpreted with caution. 
The U.S. and countries of SHARE vary considerably with respect to social expenditures. Table 3 reports by country, social expenditures as a percent of GDP by purpose: old age, health, unemployment, tertiary education, and family. ${ }^{9}$ Old age and education expenditure (-0.83) are highly (and negatively) correlated. Social expenditure on old age, unemployment and family is lower in the U.S. than in the ten European countries we study. The U.S. spends slightly more on tertiary education as a percent of GDP. There is variation across the European countries in social expenditure. Public expenditure on old age support as a percent of GDP is high in Austria, Germany and Italy and about half the spending of those countries in the Netherlands and the United States. Belgium and Denmark spend more than the other countries on unemployment, the U.S. and Greece spend the least (0.40). Public expenditure on tertiary education as a percentage of GDP is the highest in Austria (3.6\%) and lowest in Italy (0.8\%). The United States spends 1.3 percent of GDP on tertiary education. Public expenditure on 'family' is much higher in Denmark (3.5\%), Sweden (3.2\%) than in the United States, which spends less than 1 percent of GDP for these purposes (0.65\%). If transfers are earmarked for assisting with homeownership, then the size of the mortgage market may be correlated with cross-country variation in amounts of money given to children. Residential mortgage debt as a percent of GDP (Table 3) measures the size of the market or the availability of mortgage finance. It may however, also reflect ownership preferences and tax incentives. Table 3 shows Italy and Greece have the lowest levels of mortgage debt (11.4 and 13.9 respectively) and they also have low average transfers compared to the other countries, while Denmark and the Netherlands have the highest levels of mortgage debt (74.3 and 78.8 respectively) followed by the U.S. (58.0). Table 3 also reports other average country level differences that may help explain cross-country differences in the amount of money parents provide adult children: percent of the population ages 25-34 that is unemployed, attained tertiary education and fertility rate. Unemployment rates are low and tertiary education attainment and fertility are high in the United States. All of the European countries have lower fertility rates than in the U.S. while unemployment rates are generally higher in the European countries than in the U.S. The percent of the

\footnotetext{
9 The OECD Social Expenditure Database groups benefits with a social purpose in following areas: Old-age - pensions, early retirement pensions, home-help and residential services for the elderly; Health - spending on inand out-patient care, medical goods, prevention; Family - child allowances and credits, childcare support, income support during leave, sole parent payments; Unemployment - unemployment compensation, severance pay, early retirement for labour market reasons; Housing - housing allowances and rent subsidies.
} 
population aged 24-35 with a tertiary education varies in Europe with highest rates in Sweden (42\%), Belgium (41\%) and the lowest rates in Italy (15\%).

We employ multivariate methods to study how parental socio-economic status, demographics, country level social expenditures (\% of GDP), residential mortgage market and characteristics of the population explain the amount of money parents give to all their children annually pooling the 2004 data from SHARE and HRS. The first model estimates the amount of money parents give children (2004 Euros trimmed at the $98^{\text {th }}$ percentile) annually adjusting for age, marital status, education level, number of children, income, wealth and including country indicators. OLS results are given in the first column of Table $4 .{ }^{10}$ The second model includes, instead of country fixed effects, country level measures of social expenditures and characteristics described in Table 3. Because the distribution of the amount given is highly unequal, with most children not receiving any money in a given year, we also estimate quantile regressions models at the $90^{\text {th }}$ percentile (Model 3).

Estimates of model 1 confirm that income, wealth and education of parents are important predictors of the amount of money children receive. A high wealth (income) parent (top $25 \%$ of the respective distribution) transfers 635 (580) more Euros annually to all children than a low wealth (income) parent. College-educated parents transfer 492 more Euros annually to children than parents without a college degree. The effects of income and wealth are about three times larger at the $90^{\text {th }}$ percentile confirming that the largest amounts of giving are concentrated among the high income and high wealth parents (Model 3). ${ }^{11}$

Parents in all European countries represented in the SHARE data give less to children than the parents in the United States. Comparing the model estimates of country effects to the mean values in Table 1 (unconditional trimmed values), the difference in transfer amount between the U.S. and the European countries in the SHARE data is reduced by between 20 and 50 percent. Thus, the difference in giving to children between the U.S. and countries in SHARE is explained in part by cross-country differences in parents' socio-economic and demographic characteristics.

Estimates of social policy expenditures (Table 4, Model 2 and 3) show some relationship to transfer amount but are not consistent with 'crowd out' of family transfers by government expenditures. Spending on

\footnotetext{
${ }^{10}$ Based on amounts trimmed at the $98^{\text {th }}$ percentile.

${ }^{11}$ We check the sensitivity of the income results to the wave one income measure by comparing model estimates obtained using wave 2 income compared to using wave 1 income for the same sample and find the estimates are unchanged.
} 
tertiary education is positively related to parental monetary gifts to children although the amounts are small relative to these social expenditures. For example, a one percent of GDP increase in spending on 'tertiary education’ increases transfers by 262 Euros (on a base of 691 Euros). Public spending on family policies has a negative effect on giving by parents (-217 Euros) that is higher at the $90^{\text {th }}$ percentile (-358 Euros) but is again overall a small effect. The percent of the population ages 24-35 unemployed is associated with an increase in transfers although again, the magnitude is small. The fertility rate is positively associated with money given to all children: an additional child increases money given to children by 1000 Euros at the mean and just under that amount at the $90^{\text {th }}$ percentile. The size of the mortgage market has a very small, positive effect on money given to children and thus, as measured here, does not appear to be an important source for generating differences in giving across countries.

In sum, there is much heterogeneity across households and countries in the amount of money given by parents to all of their children. In all countries, some households give money to children, many do not. In part, the unequal distribution of money given to children across households is only partially explained by differences in parental socio-economic status and demographics. The amount given to children is higher in the U.S. than in Europe and within the European countries in the SHARE data, amounts are high in Denmark and Belgium and low in Spain. A high co-residency rate in Spain may explain the low probability of parental monetary transfers relative to other European countries (Albertini et al. 1007). Some of the differences in amounts parents give children across countries are explained by social public expenditure.

On average the amounts of money older parents give to all children annually in any country does not appear large enough to transmit meaningful wealth inequalities across generations. For example, in the United States, annual transfers to all children are 1862 Euros, about 580 per child. Mean transfers to all children are highest in Belgium (2688 Euros) and lowest in Spain (467 Euros). The distribution of amounts however, revealed a lot of heterogeneity in amounts of money. Five percent of U.S. parents give about 9000 Euros or more annually to children. Among the countries in SHARE, the top 5 percent give 5000 Euros or more to children each year. However, even these sums of money would not play a significant role in financial wealth disparities across countries. The estimates of the amount of money parents give children are based on a single point in time and total wealth transfers to children through the mechanism of direct financial giving will depend 
in part on how persistent transfers are over time. We examine the long panel of the HRS to shed light on this issue.

\section{Parents' Monetary Gifts to Children Over Time in the United States}

How large is the amount of money parents give children over time? Is the unequal giving at a point in time of households in the U.S. and Europe mimicked when we look over time? That is, if some households give a lot to children and persistently give a lot over time then the implication is that the intergenerational transmission of wealth inequality for these households may be larger. Moreover, within a household, how unequal are transfers given to all children at a point in time and over time? The answer to this second question may shed light on the long-standing debate in the United States on how to reconcile the unequal intervivos monetary transfer to children within a family with the equal giving of bequests. To answer both questions, we turn to the long panel of data from the HRS.

How much money do parents give adult children?

We use up to 8 waves of data from the HRS 1992-2006 to measure how much money parents give to children up to 16 years. Tables $5 \mathrm{a}$ and $5 \mathrm{~b}$ shows the distribution of amount of money parents give children for various lengths of time. Table 5a shows the money parents give to all their children (average number of children is 3.3) and Table 5b reports the per child amount. On average, over two-years parents give \$5102 and over 16 years, \$37,765 to all their children (Table 5a). Each child receives on average \$1,559 and over 16 years, $\$ 11,122$ or about $\$ 780$ per year if they are receiving money each year (Table 5b). Once again, mean amounts obscure the highly unequal nature of the distribution. Fifty percent of households give no money to children over 2 years and give \$12,368 over 16 years (Table 5a). ${ }^{12}$ Seventy five percent of children receive no money over 2 years and receive $\$ 8,622$ over 16 years or about $\$ 539$ per year (Table 5b). In contrast, at the 95 th percentile households give $\$ 23,869$ or more over two years and over 16 years give $\$ 141,636$ or more. Children in the top 5 percentile receive $\$ 7,421$ or more from parents over two years and $\$ 54,602$ or more over 16 years.

Is the amount of money given to children large?

\footnotetext{
12 Median amounts for households is \$12,368 while per child amount is just \$500 reflecting that many children are receiving no money.
} 
On average, the amount of money a child receives each year is small, about $\$ 780$. The average age of children in the HRS is 32 and average income is $\$ 45,000$. In terms of life-cycle events, the average child is not in school, is married and has a child and just under one-half do not yet own a home (Appendix B shows mean characteristics for the children of HRS respondents). Thus many children in the HRS have aged past life-cycle events that may generate parental giving, particularly college and higher education more generally. Table 5c shows the amount of money a child in school and between the ages of 17 or 18 receives over the next six years. Within this age group, the average amount a child receives is about 9,000 over two-years, $\$ 18,374$ over four years and slightly more $(\$ 21,651)$ over 6 years or about $\$ 4,600$ per year. This is about 50 percent more than all children in this age group receive (i.e. including those not in school). Annual parental transfers for college age children of $\$ 4,600$ are 50 percent of average college tuition costs in year $2005(\$ 9,144)$ and 30 percent of average tuition plus room and board expenses of \$16,048 (College Board, 2005). Many students receive some form of financial aid thereby reducing tuition, room and board expenses to an average of $\$ 11,286$. Thus parental financial transfers represent 40 percent of annual college expenses after financial aid. A child in the highest $5 \%$ receives $\$ 39,488$ or more over two-years. Twenty thousand dollars is approximately the annual tuition for a private, four-year college. Appendix C table provides a summary of average public and private college costs for year 2005. For children in college, the level of parental transfers is significant however, the question remains of how essential parental financing is in the school decision.

Table 6 shows the average household income and wealth for household based on their position in the distribution of giving to children. As expected, households that give to children have higher income and wealth than those that do not give. For example, households at the median of the two-year transfer distribution have annual income of $\$ 65,179$ and wealth of $\$ 342,639$ and households at the $95^{\text {th }}$ have $\$ 134,160$ annual income and $\$ 968,004$ in wealth. Households that give substantially to children give more as a percentage of their income and wealth. At the $75^{\text {th }}$ percentile of the transfer distribution, annual household giving represents 1.5 percent of household annual income and total household giving over 16 years is 8.7 percent of average household wealth. At the $95^{\text {th }}$ percentile of the transfer distribution, annual household giving represents 8.9 percent of household annual income and total household giving over 16 years is 16.5 percent of average household wealth.

\section{Are transfers persistent over time?}


Table 5a showed that after 16 years, fewer households gave no money to children than after 2 years, which suggests that giving by households is not persistent over time. This is also true for households that give large amounts of money to children. Table 7 shows, for the parental households in the $75^{\text {th }}$ and $90^{\text {th }}$ percentile of the 16-year transfer distribution, the percent giving in at least one, two and through eight waves. Almost three quarters (73.5) percent of household at the $75^{\text {th }}$ percentile or higher of 16 -year giving gave in at least 5 waves of data (16 years). Households farther up in the distribution gave more persistently. Eighty-eight percent of households at the $90^{\text {th }}$ percentile or higher of 16-year transfer amounts gave in at least 5 waves while 94 percent gave in at least half of the 8 waves.

To illustrate how the distribution of money given to all children changes over time,, we plot the ratio of the $75^{\text {th }}$ percentile to the median, the $90^{\text {th }}$ percentile to the median and the $90^{\text {th }}$ to the $75^{\text {th }}$ percentile in Figure 3. Transfer amounts across households become substantially more equal over time. Six-year amounts of money given to all children at the $75^{\text {th }}$ percentile is almost 8 times the median amount while the ratio of 16 year amounts reduces to just over 3. Six year amounts of money given to children at the $90^{\text {th }}$ percentile are over 24 times the median amount while the ratio of the $90^{\text {th }}$ percentile to the median of 16 year amounts reduces to 7.5. Even a the top quarter of the distribution, there are large differences in the amount of money given to all children over 2 years that reduces when the time horizon is 16 years. The ratio of the $90^{\text {th }}$ percentile to the $75^{\text {th }}$ is 4.7 but declines to 2.3 after 16 years. We find that over time, the amount of money parents give to all children becomes more equal across households. After 16 years however, 25 percent of children did not receive any money, 50 percent received $\$ 500$ or less while 5 percent received almost $\$ 55,000$.

\section{Equality of Parents' Monetary Gifts to Children Within the Family in the U.S.}

How do parents divide monetary gifts among children? A consistent empirical finding in the literature is that parents divide assets among children equally at death but give unequally while alive. These established facts, however, have been based on intervivos giving over a short period of time, usually one or two years. We turn our analysis now to studying how parents divide money among children using information provide by respondents in the HRS on amounts of money given to each child and linking children across multiple waves of data - up to 8 waves or 16 years of recorded giving to children. 


\section{Do all children in a family receive parental financial transfers?}

Table 8 shows the percent of households giving money to all their children, none of their children or only some of their children over various lengths of time from 2 years to 16 years. The sample is based on households that gave at least one time to one child over 16 years. We show results for all households and by number of children. Among all households, only 11.6 percent of parents give money to all their children (among households with two or more children) over a two year time period. This steadily increases with time and by 16 years, 43 percent of parents have given money to all their children and the remaining 57 percent to some but not all children. Households giving to no children drops quickly over 8 years from 51 percent to 16 percent. Households with 2 children are much more likely to give to all their children than households with 3 children or 4 or more. Over two years, 23 percent of households with 2 children give to all their children and only 3.6 percent of households with 4 or more children give to all of them. After 16 years, 71 percent of households with two children have given money to all their children, 40 percent of households with three children and 22 percent of households with 4 or more children. Some of this difference will reflect the lower wealth of households with more children. Difference over time in the percent of households giving to no children does not differ much by family size. That is, about half are not giving to any children at 2 years for all family sizes and by 8 years this reduces to between 14 ( 2 children) and 17 percent ( 4 or more children) for all family sizes.

\section{Do all children in a family receive the same amount of money?}

We calculate how much money parents, of more than one child, give each child summing across different lengths of time (e.g. 2 years 4 years... up to 16 years). We calculate the difference in amount between what each child receives and the average amount children in that family receive (absolute value of) divided by the average amount. Thus if all children receive the same amount, the ratio is zero. A ratio of 1 may be interpreted as a 100 percent difference between child $\mathrm{i}$ in family $\mathrm{j}$ and the average of children in family $\mathrm{j}$. We plot the mean of this ratio by number of children (2, 3, 4 or more) in Figure 4a and for low and high wealth and income in Figures 4b and 4c respectively. Two distinct patterns emerge. First, as the number of children in a family increase, so does inequality in transfer amount (level differences by number of children across all time 
periods). For example, for a 2 year time period, the mean ratio for a two-child family is 0.74 and is 1.43 for a family with 4 or more children.

After 16 years, money given to children in families with four or more children remains more unequal than money given to children in families with two children. Second, for all family sizes, the amount of money children receive becomes more equal over time. For example, over a two-year period, child i in family j receives 75 percent more (less) than her sibling but after 16 years she receives only 50 percent more (less). Thus, the level of inequality in inter-vivos giving to children is to an extent, is an artifact of the time period over which transfers are observed. High wealth or high income parents give more equally to their children than low wealth and income parents (Figures 4b and 4c) and more so over time (steeper slope of the high wealth and income lines in Figures $4 \mathrm{~b}$ and $4 \mathrm{c}$ ). In sum, the child that is most likely to be receiving the same amount of money as their sibling(s) has only one sibling and has high income and high wealth parents.

\section{Multivariate model results for short and long term money transfers to children in the U.S.}

We next study factors associated with receipt of money from a parent over different lengths of time. We model the probability a child gets money from her parents and the amount of money she gets, conditional on receiving, for a sample of children that are present in 7 waves for a total of 32,661 child/year observations. ${ }^{13}$ We estimate three models for the probability a child receives money (and 3 additional models for amount of money received) one for each of three time periods: 2 years, 8 years and 14 years and report marginal effects of covariates measured at baseline in Table 9. All covariates are measured at the initial wave. In order to interpret our findings in the context of increasing average probabilities of giving and amount given with time, we describe results in terms of percent change from the baseline probability or amount as well as overall level. Estimates of the marginal effects for key covariates are provided in Table 9 and for all in Appendix Table A.

Parents' income and wealth. We find that receipt of money over two years is highly dependent on a parent's current ability to give, as measured by income, but over a greater time period, 14 years, a long-run measure of socio-economic status, wealth, is more important than income. For example, a child with a parent in

\footnotetext{
13 The sample constrained to be in all 7 waves is about 2.5 years younger than the full sample, with the same education level and about \$5,000 more income on average.
} 
the top $25^{\text {th }}$ percent of the income distribution is 34 percent (5.5 percentage points on a baseline of 0.16 ) more likely to get money over two years than a child with a parent in the third income quartile but is only 12 percent more likely to get money over 14 years. In contrast, the likelihood a child with a high wealth parent gets money is equal (in terms of percent increase from baseline giving) over two, eight and 14 years (about 22 percent more likely relative to a child with parents in the third wealth quartile). Conditional on receiving money, the amount that a child with high income and high wealth parents receives relative to one with low income and wealth parents becomes increasingly large over time. For example, a child with a parent in the top $25^{\text {th }}$ percentile of the wealth distribution receives $\$ 2,171$ more over two years than a child with a parent in the third quartile of the wealth distribution, or 23 percent more than the two-year average, and gets over \$14,600 more over 14 years or 74 percent of the 14 year average amount. Over 14 years, there is a difference of about $\$ 18,000$ between what a child with a low wealth parent receives and what a child with a high wealth parents receives.

Children's education. In the short-term (over two-years) children get money from parents in response to their immediate needs for example to finance their higher education, compensate for their low earnings or loss of a house and for their own children. College educated children receive more money that high school educated children. This appears to be related to parents paying for college: being in school increases the baseline probability of receiving money over two years by 43 percent relative to not attending school. Over 14 years however, being in school at baseline increases the baseline probability of receiving money by only 13 percent. Children attending college (in school and highest degree is some college at baseline) receive $\$ 4,571$ more than children not in school and whose highest degree is high school over two-years. Over 14 years, the differences in the money received by children attending college at baseline (some college) and those that do not persist with those children attending college at baseline receiving $\$ 10,901$ more than those not in school and completed high school at baseline. Although we do not know whether the money received is for educational expenses, the findings are consistent with this interpretation.

Children's income. Low-income children are more likely to receive money in the short term but over time, income differences are much less predictive of receipt of money. For example, a child in the top $25^{\text {th }}$ percentile of the earnings' distribution is 10 percentage points less likely to get money from a parent than a child in the lowest earnings quartile, which represents a 62 percent decline from the baseline probability. Over 14 
years, a child in the top $25^{\text {th }}$ percentile of the earnings' distribution at baseline is 7 percentage points less likely to get money from a parent than a child in the lowest earnings quartile, which represents only a 17 percent decline from the baseline probability. Conditional on receiving a transfer, there is no difference between a high income child and a low income child in the amount of money a child receives.

Children's housing and children. Children who are homeowners are less likely to receive money from parents although the effect of being a new homeowner is no different than not being a homeowner. Conditional on receiving money from parents, children that become homeowners over 2 years or were homeowners and lost a home received $\$ 2,488$ and $\$ 6,693$ respectively more than children that were never homeowners over 2 years but there is no difference in money received after 14 years. The magnitude of these numbers suggests that on average, assisting with homeownership does not appear to be an important factor driving parental transfers. Finally, the likelihood of giving to children increases with the number of grandchildren particularly in the shortrun. For example, a child with 4 or more children is 5 percentage points more likely to receive money from parents over two-years than a child without children (30 percent increase from the baseline probability) and the differences between children with and without children diminishes over time.

In sum, a short-term view of money given to children from parents would suggest giving is to an extent compensatory (low earnings), based on immediate need (for a new house or loss of a house, to finance education for grandchildren) and the amount given for any of these needs is not large. Over a long-time horizon, a child's education is one of the remaining sources of difference in money given to children. Children in college or in school with a college degree received more money over the next 14 years than those not in school and with a high school degree although again, the difference in amount is not large.

4. Conclusion

Although the likelihood parents gave money to their children each year and the amount they gave varied across the United States and the ten European countries we studied, the average amounts they gave annually were not enough to affect wealth inequalities across generations in any country even if given persistently over time. Data on monetary gifts to children over time in the U.S. revealed that giving was most persistent among households that gave high amounts to children over two years. Children received money in response to 
immediate needs in the short term (low income, housing, school). The average two-year amount a child received from parents was about $\$ 1,560$ and $\$ 11,120$ over 16 years, thus the magnitude of inter-vivos transfers over time is simply not large enough to affect the distribution of resources within or between families in the next generation. The timing and level of financial transfers, for example to smooth consumption after an income shock or to finance higher education, however may have a significant impact on the welfare of a child. Annual parental transfers for college age children in the U.S. were 50 percent of average college tuition costs in year 2005 and 30 percent of average tuition plus room and board expenses. The effect of parental transfers to finance higher education on intergenerational mobility in the U.S. will depend in part upon whether the financing is essential in the schooling decision.

Moreover, parental monetary transfers for college and higher education are just one part of many factors generating intergenerational transmission of human capital accumulation and may not be the most important part. For example, in Spain, only 15 percent of individuals ages 55-64 have a college degree but 39 percent of individuals ages 25-34 have a college degree and direct monetary transfers to children are the lowest of all the countries we studied, an average of 470 Euros annually (although co-residency is high). In contrast, in Italy, 9 percent of individuals ages 55-64 have a college degree and only 16 percent of individuals ages 25-34 have a college degree. Parental monetary transfers to children in Italy, while higher than in Spain (873 Euros annually), are still low. In both countries, public expenditure on tertiary education is high, and much higher than in United States. Additional study is needed to better understand how parental financial investment in higher education impacts intergenerational mobility through education and is affected by public provision of higher education financing. Panel micro data on parental transfers for children’s education and methods utilizing crosscountry and over time variation in public expenditure on education offers a promising avenue for this research. 
References

Albertini, Marco, Martin Kohli and Claudia Vogel, 2007. "Intergenerational transfers of money in European families: common patterns different regimes?” Journal of European Social Policy, Vol. 17, pp 319-334.

Altonji, Joseph G., Fumio Hayashi, and Laurence J. Kotlikoff. 1997. "Parental Altruism and Inter Vivos Transfers: Theory and Evidence,” Journal of Political Economy, Vol. 105, No. 6, December, pp. 11211166.

Barro, Robert J. 1974. “Are Government Bonds Net Wealth?” Journal of Political Economy, Vol. 82, No. 6, November-December, pp. 1095-1117.

Becker, Gary S. 1974. "A Theory of Social Interactions,” Journal of Political Economy, Vol. 82, No. 6, November-December, pp.1063-1093.

Becker, Gary S. 1981. A Treatise on the Family, Cambridge, MA: Harvard University Press.

Bernheim, B. Douglas, Andrei Shleifer, and Lawrence H. Summers. 1985. “The Strategic Bequest Motive,” Journal of Political Economy, Vol. 93, No. 6, pp.1045-1076.

Brown, Meta, Maurizio Mazzocco, John Karl Scholz, Ananth Seshadri. 2006. “Tied Transfers,” Working Paper University of Wisconsin.

Chiuri, Maria and Tullio Jappelli. 2003. "Financial market imperfections and home ownership: a comparative study,” European Economic Review, Vol. 47(5), pp. 857-875.

Cox, Donald. 1987. “Motives for Private Income Transfers,” Journal of Political Economy, Vol. 95, pp. 508546.

Cox, Donald and Tullio Jappelli. 1990. "Credit Rationing and Private Transfers: Evidence from Survey Data," The Review of Economics and Statistics, Vol. 72(3), pp. 445-454.

Gale, William G., and John Karl Scholz. 1994. "Intergenerational Transfers and the Accumulation of Wealth,” Journal of Economic Perspectives, Vol. 8, No. 4, pp. 145-160.

Guiso, Luigi and Tullio Jappelli. 2002. "Private transfers, borrowing constraints and the timing of home ownership,”Journal of Money, Credit and Banking, Vol. 34, pp. 315-339.

McGarry, Kathleen. 2001. “The Cost of Equality: Unequal Bequests and Tax Avoidance,” Journal of Public Economics, Vol. 79, No. 1, January, pp. 179-204.

McGarry, Kathleen, and Robert F. Schoeni. 1995. "Transfer Behavior in the Health and Retirement Study. Measurement and the Redistribution of Resources within the Family,” Journal of Human Resources, Vol. 30, pp. S184-S225.

McGarry, Kathleen, and Robert F. Schoeni. 1997. "Transfer Behavior Within the Family: Results from the Asset and Health Dynamics Survey,” Journal of Gerontology, Vol. 52B, pp. 82-92.

OECD Family Database, 2008 (www.oecd.org/els/social/family/database).

Poterba, James. 1998. “Estate and Gift Taxes and Incentive for Inter Vivos Giving in the United States,” National Bureau of Economic Research Working Paper 6842, December. 
Yaari, Menahem E. 1965. "Uncertain Lifetime, Life Insurance and the Theory of the Consumer,” Review of Economic Studies, Vol. 32, pp. 137-150. 
Table 1. Money Given by Parents to ALL Children in Year 2004 by Country (Amounts in 2004 Euros)

\begin{tabular}{|c|c|c|c|c|c|c|c|c|c|c|c|}
\hline & & \multirow{2}{*}{\multicolumn{4}{|c|}{ Unconditional }} & & & \multicolumn{4}{|c|}{ Trimmed at $98^{\text {th }}$ Perc. } \\
\hline & & & & & & \multicolumn{2}{|c|}{ Conditional } & \multicolumn{3}{|c|}{ Unconditional } & \multirow{2}{*}{$\begin{array}{l}\text { Cond. } \\
\text { Mean } \\
\end{array}$} \\
\hline & & $\%$ & Mean & 90th & 95th & Mean & Median & Mean & 90th & 95th & \\
\hline Austria & 1,161 & 26.4 & 1,062 & 2,000 & 4,057 & 4,021 & 1,500 & 476 & 2,000 & 3,000 & 1,941 \\
\hline Belgium & 2,186 & 19.1 & 2,688 & 3,000 & 7,500 & 14,109 & 3,114 & 723 & 2,000 & 5,000 & 4,237 \\
\hline Denmark & 1,027 & 25.2 & 1,219 & 3,125 & 7,125 & 4,838 & 2,561 & 708 & 2,689 & 4,033 & 3,037 \\
\hline France & 1,801 & 18.7 & 1,439 & 2,400 & 6,000 & 7,716 & 2,602 & 577 & 1,587 & 4,000 & 3,429 \\
\hline Germany & 1,676 & 26.9 & 968 & 2,600 & 5,000 & 3,603 & 2,000 & 603 & 2,000 & 4,000 & 2,380 \\
\hline Greece & 1,712 & 24.8 & 1,174 & 3,000 & 6,000 & 4,738 & 2,000 & 636 & 2,000 & 4,000 & 2,740 \\
\hline Italy & 1,530 & 16.1 & 841 & 1,038 & 4,000 & 5,233 & 1,695 & 307 & 1,000 & 2,000 & 2,169 \\
\hline Netherlands & 1,708 & 19.1 & 1,037 & 2,000 & 5,000 & 5,427 & 2,500 & 507 & 1,545 & 3,840 & 2,897 \\
\hline Spain & 1,492 & 8.4 & 467 & 0 & 1,803 & 5,549 & 3,000 & 139 & 0 & 744 & 2,256 \\
\hline Sweden & 1,936 & 27.4 & 660 & 2,179 & 3,268 & 2,410 & 1,307 & 450 & 1,634 & 2,723 & 1,737 \\
\hline U.S. & 11,861 & $38.9^{*}$ & 1,862 & 4,484 & 8,969 & 4,795 & 1,794 & 1,098 & 4,077 & 6,523 & 2,939 \\
\hline SHARE & 16,229 & 19.7 & 1,012 & 2,000 & 5,000 & 5,127 & 2,000 & 463 & 1,500 & 3,000 & 2,579 \\
\hline
\end{tabular}

Source: 2004 SHARE Release 2.3.0 and 2004 HRS

Notes: *U.S. percent giving based on average over 2-years. Estimated one-year giving is 25.2 percent.

Weighted results. 
Table 2. Characteristics of Parents by Country

\begin{tabular}{rrrrrrrr} 
& & & & \multicolumn{2}{c}{2004} & 2006 \\
\cline { 5 - 8 } Country & $\mathrm{N}$ & Percent & Percent & Mean & \multicolumn{3}{c}{ Mean (Euros) } \\
\hline Austria & 1,161 & 56 & 21 & 2.26 & 167,037 & 26,356 & 31,306 \\
Belgium & 2,186 & 65 & 25 & 2.43 & 305,576 & 28,193 & 36,051 \\
Denmark & 1,027 & 56 & 30 & 2.45 & 279,279 & 43,714 & 55,695 \\
France & 1,801 & 59 & 18 & 2.53 & 299,710 & 36,284 & 29,337 \\
Germany & 1,676 & 59 & 24 & 2.22 & 165,006 & 28,816 & 26,920 \\
Greece & 1,712 & 62 & 12 & 2.16 & 191,152 & 14,222 & 36,444 \\
Italy & 1,530 & 66 & 6 & 2.35 & 220,543 & 16,332 & 24,741 \\
Netherlands & 1,708 & 65 & 17 & 2.71 & 221,017 & 31,507 & 35,718 \\
Spain & 1,492 & 66 & 9 & 2.75 & 307,708 & 32,451 & 31,879 \\
Sweden & 1,936 & 58 & 20 & 2.50 & 245,206 & 33,025 & 43,842 \\
United States & 11,861 & 54 & 22 & 3.22 & 330,404 & 48,589 & na \\
\hline All SHARE & 16,229 & 62 & 16 & 2.42 & 234,242 & 28,007 & 30,115 \\
\hline
\end{tabular}

Source: 2004 SHARE Release 2.3.0 and 2004 HRS

Notes: Weighted results.

${ }^{1}$ Net wealth is sum of stocks, bonds, iras, checking, savings, business, house, other, less debt and mortgage.

${ }^{2}$ Income is sum of household income from: earnings, pensions, transfers, assets, other; includes only regular payments (e.g. no lump sums or support by family members). Income in SHARE wave 1 had substantial non-response. Although imputations were computed with a conditional hot deck for responses bracketed into income categories, there was also substantial non-response to the brackets thus the mean values reported for wave 1 should be interpreted with caution. ${ }^{3}$ Because of income non-response in wave 1, we also report 2006 net income for $81 \%$ of the SHARE sample for which it is available in Wave 2 Release 2.3.0 (weighted). 
Table 3. Country Level Social Expenditure and Population Level Statistics

As \% of GDP $\quad$ For Ages 25-34

\begin{tabular}{|c|c|c|c|c|c|c|c|c|c|}
\hline Country & Old Age & Health & Unemp. & $\begin{array}{l}\text { Tert. } \\
\text { Educ. }\end{array}$ & Family & $\begin{array}{r}\text { Mortgage } \\
\text { Debt }\end{array}$ & $\begin{array}{r}\text { Unemployed } \\
(\%)\end{array}$ & $\begin{array}{l}\text { Tertiary } \\
\text { Educ. } \\
\text { (\%) }\end{array}$ & Fertility Rate \\
\hline Austria & 12.7 & 6.7 & 1.2 & 3.6 & 2.9 & 19.0 & 5.5 & 20.3 & 1.42 \\
\hline Belgium & 7.1 & 7.5 & 3.4 & 1.3 & 2.6 & 27.9 & 10.0 & 40.7 & 1.72 \\
\hline Denmark & 7.1 & 5.9 & 3.3 & 2.4 & 3.5 & 74.3 & 5.8 & 37.6 & 1.78 \\
\hline France & 10.7 & 7.8 & 1.8 & 1.2 & 3.0 & 22.8 & 9.7 & 38.4 & 1.90 \\
\hline Germany & 11.2 & 7.6 & 1.7 & 1.1 & 1.9 & 54.0 & 11.5 & 22.9 & 1.36 \\
\hline Greece & 10.4 & 5.1 & 0.4 & 1.4 & 1.2 & 13.9 & 12.4 & 25.3 & 1.31 \\
\hline Italy & 11.5 & 6.6 & 0.5 & 0.8 & 1.3 & 11.4 & 10.3 & 14.8 & 1.33 \\
\hline Netherlands & 5.6 & 5.8 & 1.6 & 1.4 & 1.6 & 78.8 & 4.6 & 34.5 & 1.73 \\
\hline Spain & 7.9 & 5.8 & 2.2 & 0.9 & 2.1 & 32.3 & 9.6 & 38.1 & 1.33 \\
\hline Sweden & 9.8 & 6.8 & 1.3 & 1.9 & 3.2 & 40.4 & 8.7 & 42.3 & 1.75 \\
\hline U.S. & 5.4 & 6.9 & 0.4 & 1.3 & 0.7 & 58.0 & 5.1 & 39.0 & 2.05 \\
\hline All SHARE & 10.2 & 6.9 & 1.5 & 1.2 & 2.1 & 34.5 & 10.0 & 28.3 & 1.50 \\
\hline
\end{tabular}

Sources: Social Expenditure Database-Social and Welfare Statistics, OECD Education at a Glance, 2008; Social

Expenditure Database-ELS Pensions; Social Expenditure Database-Labour Force Statistics; Social Expenditure DatabaseGeneral Statistics; OECD Economic Outlook (2004); IMF World Economic Outlook, April 2008

Notes: Tertiary education (\% of GDP) for year 2005, mortgage debt for year 2002; all other statistics for year 2004.

Residential mortgage debt from OECD Economic Outlook 2004. Austria source is World Economic Outlook, April 2008.

Tertiary education (\% of GDP) - Direct public expenditure on educational institutions plus public subsidies to households (which include subsidies for living costs) and other private entities..

The OECD Social Expenditure Database groups benefits with a social purpose in following areas:

Old-age - pensions, early retirement pensions, home-help and residential services for the elderly;

Health - spending on in- and out-patient care, medical goods, prevention;

Family - child allowances and credits, childcare support, income support during leave, sole parent payments;

Unemployment - unemployment compensation, severance pay, early retirement for labour market reasons;

Housing - housing allowances and rent subsidies.

Fertility rate is the number of children born to women ages 15-49. 
Table 4. Linear Regression Model of Amount of Money Parents Give ALL Children (2004 Euros)

\begin{tabular}{|c|c|c|c|}
\hline Model & $\begin{array}{l}\text { Mean } \\
(1)\end{array}$ & $\begin{array}{l}\text { Mean } \\
(2)\end{array}$ & $\begin{array}{l}\text { 90th Perc. } \\
\text { (3) }\end{array}$ \\
\hline Constant & $2,630.4^{* *}$ & 91.4 & $3,398.6^{* *}$ \\
\hline Male & 27.2 & 27.8 & $63.3^{*}$ \\
\hline Age & $-57.8^{* *}$ & $-57.9 * *$ & $-146.0 * *$ \\
\hline Age squared & $0.337^{* *}$ & $0.338^{* *}$ & $0.889 * *$ \\
\hline Married & $-83.1^{* *}$ & $-82.4^{* *}$ & $-116.9 * *$ \\
\hline College & $491.9 * *$ & $491.9 * *$ & $1,565.5^{* *}$ \\
\hline \multicolumn{4}{|l|}{ [1 child] } \\
\hline 2 children & $106.9^{* *}$ & $106.9 * *$ & $135.3 * *$ \\
\hline $\begin{array}{l}3 \text { or more children } \\
\text { [Income quartile 1] }\end{array}$ & \multicolumn{2}{|c|}{ [Income quartile 1] } & 54.6 \\
\hline Income quartile 2 & $88.5^{* *}$ & $88.4^{* *}$ & $183.5^{* *}$ \\
\hline Income quartile 3 & $180.1^{* *}$ & $179.7 * *$ & $564.7 * *$ \\
\hline $\begin{array}{l}\text { Income quartile } 4 \\
\text { [Wealth quartile 1] }\end{array}$ & $580.3 * *$ & $579.7 * *$ & $1,886.1 * *$ \\
\hline Wealth quartile 2 & $130.9 * *$ & $130.8^{* *}$ & $189.3^{* *}$ \\
\hline Wealth quartile 3 & $310.4 * *$ & $310.2 * *$ & $743.2^{* *}$ \\
\hline Wealth quartile 4 & $635.2^{* *}$ & $634.9 * *$ & $1,985.9 * *$ \\
\hline \multicolumn{4}{|l|}{ [United States] } \\
\hline Austria & $-475.3 * *$ & & \\
\hline Belgium & $-226.2 * *$ & & \\
\hline Denmark & $-319.9 * *$ & & \\
\hline France & $-330.9 * *$ & & \\
\hline Germany & $-308.7^{* *}$ & & \\
\hline Greece & $-211.1^{* *}$ & & \\
\hline Italy & $-520.7 * *$ & & \\
\hline Netherlands & $-365.5^{* *}$ & & \\
\hline Spain & $-726.1^{* *}$ & & \\
\hline Sweden & $-458.2 * *$ & & \\
\hline \multicolumn{4}{|l|}{$\begin{array}{l}\text { Social Expenditures (\% of } \\
\text { GDP) }\end{array}$} \\
\hline Old age & & -13.7 & 15.1 \\
\hline Health & & -10.5 & -2.1 \\
\hline Tertiary Education & & $261.7 * *$ & $358.5^{* *}$ \\
\hline Family & & $-217.3^{*}$ & $-358.3 * *$ \\
\hline Unemployment & & 71.4 & 41.7 \\
\hline \multicolumn{4}{|l|}{ Among Ages $25-34 \%$ : } \\
\hline Unemployed & & $94.9 * *$ & $105.9 * *$ \\
\hline Tertiary Educated & & -10.2 & 3.4 \\
\hline Fertility Rate & & $1,086.4^{* *}$ & $925.4 * *$ \\
\hline Mortgage Debt (\% GDP) & & $2.61 *$ & $4.46^{* *}$ \\
\hline $\mathrm{N}$ & 27,472 & 27,472 & 27,472 \\
\hline R-squared & 0.086 & 0.086 & 0.15 \\
\hline Value of dependent variable & 690.78 & 690.78 & 2178.65 \\
\hline
\end{tabular}

Source: 2004 SHARE Release 2.3.0 and 2004 HRS

Notes: Dependent variable 'amount of money' trimmed at the $98^{\text {th }}$ percentile, * significant at $5 \%$; ** significant at $1 \%$. See notes on Table 3 for definitions of social expenditures. 
Table 5a. Amount of Money Parents Give ALL Children Over Time in the U.S.

\begin{tabular}{lrrrrrrrrr} 
Percentile & \multicolumn{2}{c}{2 years } & \multicolumn{1}{c}{ 4 years } & \multicolumn{1}{c}{ years } & 8 years & 10 years & 12 years & 14 years & \multicolumn{2}{c}{16 years } \\
\cline { 2 - 9 } & 10 & 0 & 0 & 0 & 0 & 0 & 0 & 0 & 0 \\
& 25 & 0 & 0 & 0 & 0 & 0 & 0 & 560 & 1,575 \\
& 50 & 0 & 0 & 1,437 & 2,874 & 4,482 & 6,184 & 8,908 & 12,368 \\
& 75 & 2,474 & 6,614 & 11,266 & 16,337 & 22,187 & 27,426 & 33,635 & 40,630 \\
& 90 & 11,707 & 24,075 & 35,403 & 47,358 & 58,853 & 68,534 & 80,551 & 92,164 \\
& 95 & 23,869 & 45,091 & 62,119 & 80,817 & 96,367 & 110,385 & 126,097 & 141,636 \\
Mean & 99 & 70,244 & 122,134 & 172,595 & 221,010 & 265,333 & 295,793 & 326,740 & 367,318 \\
No. of Obs. & 5,102 & 9,885 & 14,623 & 19,450 & 24,413 & 28,770 & 33,595 & 37,765 \\
& 88,168 & 68,206 & 51,450 & 38,257 & 26,816 & 16,868 & 9,926 & 3,903 \\
\hline
\end{tabular}

Table 5b. Amount of Money Parents Give A Child Over Time in the U.S.

\begin{tabular}{lrrrrrrrrr} 
Percentile & \multicolumn{2}{c}{2 years } & \multicolumn{1}{c}{4 years } & 6 years & 8 years & 10 years & 12 years & 14 years & \multicolumn{2}{c}{16 years } \\
\cline { 2 - 9 } & 10 & 0 & 0 & 0 & 0 & 0 & 0 & 0 & 0 \\
& 25 & 0 & 0 & 0 & 0 & 0 & 0 & 0 & 0 \\
& 50 & 0 & 0 & 0 & 0 & 0 & 0 & 0 & 500 \\
& 75 & 0 & 585 & 1,437 & 2,597 & 3,927 & 5,215 & 6,614 & 8,622 \\
& 90 & 2,561 & 6,376 & 10,471 & 13,976 & 18,387 & 21,879 & 25,865 & 29,905 \\
& 95 & 7,421 & 15,019 & 22,454 & 29,134 & 35,379 & 40,863 & 47,411 & 54,602 \\
Mean & 99 & 28,738 & 49,472 & 66,523 & 83,799 & 100,732 & 110,599 & 125,376 & 137,641 \\
No. of Obs. & 1,559 & 3,025 & 4,444 & 5,907 & 7,376 & 8,577 & 9,981 & 11,122 \\
& 300,669 & 229,373 & 171,771 & 126,807 & 88,571 & 55,612 & 32,661 & 12,830 \\
\hline
\end{tabular}

Table 5c. Amount of Money Parents Give a 17 or 18 Year Old Child in School Over the Next 6 Years

\begin{tabular}{|c|c|c|c|c|}
\hline \multirow[t]{8}{*}{ Percentile } & & 2 years & 4 years & 6 years \\
\hline & 10 & 0 & 0 & 0 \\
\hline & 25 & 0 & 1,360 & 2,341 \\
\hline & 50 & 2,474 & 8,392 & 11,336 \\
\hline & 75 & 11,206 & 24,736 & 29,776 \\
\hline & 90 & 27,206 & 48,681 & 54,973 \\
\hline & 95 & 39,488 & 74,440 & 82,397 \\
\hline & 99 & 84,047 & 136,841 & 140,439 \\
\hline Mean & & 9,216 & 18,374 & 21,651 \\
\hline No. of Obs. & & 2,000 & 1,523 & 1,144 \\
\hline
\end{tabular}

Source: HRS waves 1992 to 2006

Note: All amounts in \$2006 
Table 6. Average Parent Income and Wealth Based on Position in Transfer Distribution

\begin{tabular}{|c|c|c|c|c|c|c|c|c|c|}
\hline \multirow{2}{*}{\multicolumn{2}{|c|}{$\begin{array}{l}\text { Transfer } \\
\text { Percentile }\end{array}$}} & \multicolumn{8}{|c|}{ Average income (\$2006) } \\
\hline & & 2 years & 4 years & 6 years & 8 years & 10 years & 12 years & 14 years & 16 years \\
\hline \multicolumn{10}{|c|}{10} \\
\hline & 25 & & & & & & & 53,918 & 57,742 \\
\hline & 50 & & & 63,456 & 65,371 & 65,783 & 66,352 & 69,351 & 73,930 \\
\hline & 75 & 79,963 & 85,833 & 84,920 & 88,082 & 89,861 & 91,159 & 91,088 & 93,228 \\
\hline & 90 & 129,328 & 103,399 & 107,299 & 109,144 & 107,403 & 97,645 & 106,830 & 115,898 \\
\hline & 95 & 134,160 & 149,612 & 144,170 & 153,037 & 142,747 & 149,762 & 148,081 & 146,638 \\
\hline & 99 & 207,954 & 203,318 & 244,447 & 263,879 & 266,910 & 249,607 & 269,637 & 245,059 \\
\hline \multirow{2}{*}{\multicolumn{2}{|c|}{ No. Obs. }} & 88,168 & 68,206 & 51,450 & 38,257 & 26,816 & 16,868 & 9,926 & 3,903 \\
\hline & & \multicolumn{8}{|c|}{ Average wealth (\$2006) } \\
\hline \multicolumn{10}{|l|}{ Transfer } \\
\hline Percentile & & 2 years & 4 years & 6 years & 8 years & 10 years & 12 years & 14 years & 16 years \\
\hline \multicolumn{10}{|c|}{10} \\
\hline & 25 & & & & & & & 230,276 & 239,125 \\
\hline & 50 & & & 323,373 & 323,120 & 322,224 & 314,206 & 302,363 & 310,426 \\
\hline & 75 & 483,665 & 508,441 & 500,075 & 524,088 & 501,630 & 492,904 & 497,107 & 468,133 \\
\hline & 90 & 738,121 & 679,024 & 694,924 & 668,382 & 663,007 & 640,974 & 585,190 & 590,030 \\
\hline & 95 & 968,004 & $1,023,683$ & $1,070,261$ & $1,051,883$ & 982,176 & 935,639 & 867,894 & 856,740 \\
\hline & 99 & $2,349,257$ & $2,339,929$ & $1,930,942$ & $2,110,465$ & $2,114,367$ & $\begin{array}{l}7 \quad 1,980,913 \\
\end{array}$ & $1,963,744$ & $2,071,066$ \\
\hline No. Obs. & & 88,168 & 68,206 & 51,450 & 38,257 & 26,816 & 16,868 & 9,926 & 3,903 \\
\hline
\end{tabular}

Source: HRS waves 1992 to 2006

Notes:

1. All amounts in $\$ 2006$

2. Income and wealth of parents that make positive transfers (see Table 5a) 
Table 7. Persistence of Giving by High Giving Households

\begin{tabular}{ccc} 
\% of Parents That & 16-Year Transfers (\$s) at & 16-Year Transfers (\$s) at \\
Gave in at Least: & 75th percentile and above & 90th percentile and above \\
\cline { 2 - 3 } 8 waves & 14.8 & 24.2 \\
7 waves & 33.3 & 49.6 \\
6 waves & 54.3 & 73.2 \\
5 waves & 73.5 & 87.5 \\
4 waves & 85.1 & 93.9 \\
3 waves & 94.4 & 99.0 \\
2 waves & 98.3 & 99.7 \\
1 waves & 100.0 & 100.0 \\
\hline N & 937 & 351 \\
\hline Source: HRS waves 1992 to 2006 & &
\end{tabular}

Table 8. Percent of Multi-Child Households Giving Money to All Children in the Household

\begin{tabular}{|c|c|c|c|c|c|c|c|c|c|c|c|c|}
\hline \multirow[b]{3}{*}{ Time } & \multicolumn{12}{|c|}{ \% Household Giving To: } \\
\hline & \multicolumn{3}{|c|}{ All households } & \multicolumn{3}{|c|}{2 kids } & \multicolumn{3}{|c|}{3 kids } & \multicolumn{3}{|c|}{ 4+ kids } \\
\hline & All kids & $\begin{array}{r}\text { No } \\
\text { Kids }\end{array}$ & $\begin{array}{r}\text { Some } \\
\text { Kids }\end{array}$ & All kids & $\begin{array}{r}\text { No } \\
\text { Kids }\end{array}$ & $\begin{array}{r}\text { Some } \\
\text { Kids }\end{array}$ & All kids & $\begin{array}{r}\text { No } \\
\text { Kids }\end{array}$ & $\begin{array}{r}\text { Some } \\
\text { Kids }\end{array}$ & All kids & $\begin{array}{r}\text { No } \\
\text { Kids }\end{array}$ & $\begin{array}{r}\text { Some } \\
\text { Kids }\end{array}$ \\
\hline 2 Years & 11.6 & 51.4 & 37.0 & 22.5 & 48.3 & 29.1 & 9.6 & 52.7 & 37.7 & 3.6 & 53.0 & 43.3 \\
\hline 4 Years & 19.3 & 33.6 & 47.1 & 36.1 & 30.9 & 33.0 & 16.7 & 35.0 & 48.3 & 6.6 & 35.0 & 58.3 \\
\hline 6 Years & 25.4 & 23.1 & 51.5 & 46.2 & 20.6 & 33.2 & 22.6 & 24.4 & 53.0 & 9.7 & 24.3 & 66.1 \\
\hline 8 Years & 30.1 & 16.1 & 53.8 & 53.6 & 14.2 & 32.2 & 27.1 & 17.2 & 55.7 & 12.3 & 16.8 & 70.8 \\
\hline 10 Yrs & 33.8 & 11.0 & 55.2 & 59.1 & 9.8 & 31.1 & 30.9 & 11.7 & 57.4 & 14.6 & 11.5 & 73.9 \\
\hline 12 Yrs & 37.2 & 6.6 & 56.2 & 63.9 & 5.8 & 30.3 & 34.4 & 7.1 & 58.5 & 16.8 & 7.0 & 76.2 \\
\hline 14 Yrs & 39.8 & 3.0 & 57.3 & 67.3 & 2.1 & 30.6 & 36.9 & 3.4 & 59.7 & 18.9 & 3.4 & 77.8 \\
\hline 16 Yrs & 42.8 & 0.0 & 57.2 & 70.6 & 0.0 & 29.4 & 40.3 & 0.0 & 59.7 & 21.5 & 0.0 & 78.5 \\
\hline
\end{tabular}

Source: HRS waves 1992 to 2006

Note: The sample is b. 1931-1941 entering the HRS in 1992 and has given money to children at some time over the 8 waves. The pattern is the same for other cohorts. 
Table 9. Linear Regression Model Results for Money Parents Give a Child over 2, 8, and 14 Years Probability Child Receives Money Amount of Money

\begin{tabular}{|c|c|c|c|c|c|c|}
\hline \multirow{2}{*}{ PARENT COVARIATE } & \multirow[t]{2}{*}{2 Years } & \multirow[t]{2}{*}{8 Years } & \multirow[t]{2}{*}{14 Years } & \multirow[t]{2}{*}{2 Years } & \multirow[t]{2}{*}{8 Years } & \multirow[t]{2}{*}{14 Years } \\
\hline & & & & & & \\
\hline \multicolumn{7}{|l|}{ Parent Wealth Quartiles: } \\
\hline 1 & $-0.052 * *$ & $-0.127 * *$ & $-0.138 * *$ & $-2,196 * *$ & $-2,925 * *$ & $-3,367 *$ \\
\hline 2 & $-0.023 * *$ & $-0.049 * *$ & $-0.051 * *$ & $-1,445^{*}$ & $-1,411^{*}$ & $-1,381$ \\
\hline \multicolumn{7}{|l|}{ [3 omitted] } \\
\hline 4 & $0.037 * *$ & $0.081^{* *}$ & $0.097 * *$ & $2,171^{* *}$ & $7,879 * *$ & $14,600^{* *}$ \\
\hline \multicolumn{7}{|l|}{ Parent Income Quartiles: } \\
\hline 1 & $-0.079 * *$ & $-0.129 * *$ & $-0.147 * *$ & -165 & $-3,201 * *$ & $-6,488 * *$ \\
\hline 2 & $-0.041 * *$ & $-0.062 * *$ & $-0.060 * *$ & -998 & $-1,373^{*}$ & $-3,073^{*}$ \\
\hline \multicolumn{7}{|l|}{ [3 omitted] } \\
\hline 4 & $0.055^{* *}$ & $0.059 * *$ & $0.054^{* *}$ & $2,578 * *$ & $5,687 * *$ & $11,657^{* *}$ \\
\hline \multicolumn{7}{|l|}{ CHILD COVARIATE } \\
\hline In school & $0.069 * *$ & $0.058^{* *}$ & $0.058 * *$ & $-1,744$ & $4,200^{*}$ & 2,980 \\
\hline \multicolumn{7}{|l|}{ Education at baseline: } \\
\hline Less than High School & -0.012 & -0.014 & $-0.022 *$ & $-1,462$ & -453 & 455 \\
\hline Some College & 0.008 & $0.021 * *$ & $0.024 * *$ & 139 & 531 & -386 \\
\hline College & 0.010 & 0.003 & -0.000 & $1,583^{*}$ & $1,463^{*}$ & $3,005^{*}$ \\
\hline \multicolumn{7}{|l|}{ In school * high ed: } \\
\hline In school*less HS & -0.034 & 0.006 & -0.006 & 3,253 & $-2,799$ & $-3,190$ \\
\hline In school*some college & $0.123^{* *}$ & $0.070 * *$ & 0.026 & $6,176 * *$ & $4,033^{*}$ & $8,307^{*}$ \\
\hline In school*college & $0.077 * *$ & 0.037 & 0.003 & $3,729 *$ & -657 & 1,367 \\
\hline \multicolumn{7}{|l|}{ Homeownership: } \\
\hline Own home & $-0.021 * *$ & $-0.060^{* *}$ & $-0.055^{* *}$ & $2,331 * *$ & 1,367 & 1,360 \\
\hline New home & 0.018 & $0.041^{*}$ & 0.023 & 157 & -894 & $-2,408$ \\
\hline Same home & $-0.029 * *$ & -0.020 & $-0.027 *$ & $-1,105$ & 43 & $-2,540$ \\
\hline Lose home & 0.005 & 0.022 & 0.025 & $4,362 *$ & 1,373 & 2,765 \\
\hline \multicolumn{7}{|l|}{ Number of children: } \\
\hline 1 to 3 & $0.022 * *$ & $0.055^{* *}$ & $0.067 * *$ & -862 & 468 & 2,616 \\
\hline 4 or more & $0.049 * *$ & $0.072 * *$ & $0.075 * *$ & 318 & 501 & 2,267 \\
\hline Co-resides with parent & 0.006 & $0.068 * *$ & $0.085 * *$ & $1,405^{*}$ & $2,192 * *$ & 3,180 \\
\hline Lives close to parent & $0.017^{* *}$ & $0.035^{* *}$ & $0.048 * *$ & 539 & $1,613^{* *}$ & 1,455 \\
\hline \multicolumn{7}{|l|}{$\begin{array}{l}\text { Earnings Quartiles: } \\
\text { [1 omitted] }\end{array}$} \\
\hline 2 & $-0.024 * *$ & $-0.016 *$ & -0.002 & -343 & -957 & -526 \\
\hline 3 & $-0.079 * *$ & $-0.064 * *$ & $-0.037 * *$ & -256 & $-2,378 * *$ & $-2,849$ \\
\hline 4 & $-0.101^{* *}$ & $-0.099 * *$ & $-0.073 * *$ & -189 & $-1,619$ & $-1,168$ \\
\hline $\mathrm{N}$ & 32,661 & 32,661 & 32,661 & 5,300 & 11,768 & 14,409 \\
\hline R-squared & 0.152 & 0.213 & 0.234 & 0.087 & 0.124 & 0.069 \\
\hline $\begin{array}{l}\text { Mean Dependent } \\
\text { Variable }\end{array}$ & 0.162 & 0.36 & 0.441 & 9,368 & 14,455 & 19,858 \\
\hline
\end{tabular}

Source: HRS 1992-2006 Sample of respondents present in 7 waves

Notes: All Covariates measured at baseline

(1) Model also includes other parent and child characteristics-see Appendix Table A

(2) All amounts CPI adjusted (transfers, income, wealth, earnings)

(3) * significant at $5 \%$; ** significant at $1 \%$ 
Figure 1. Amount of Money Given to Children by Parent Age for the United States and European Countries in SHARE

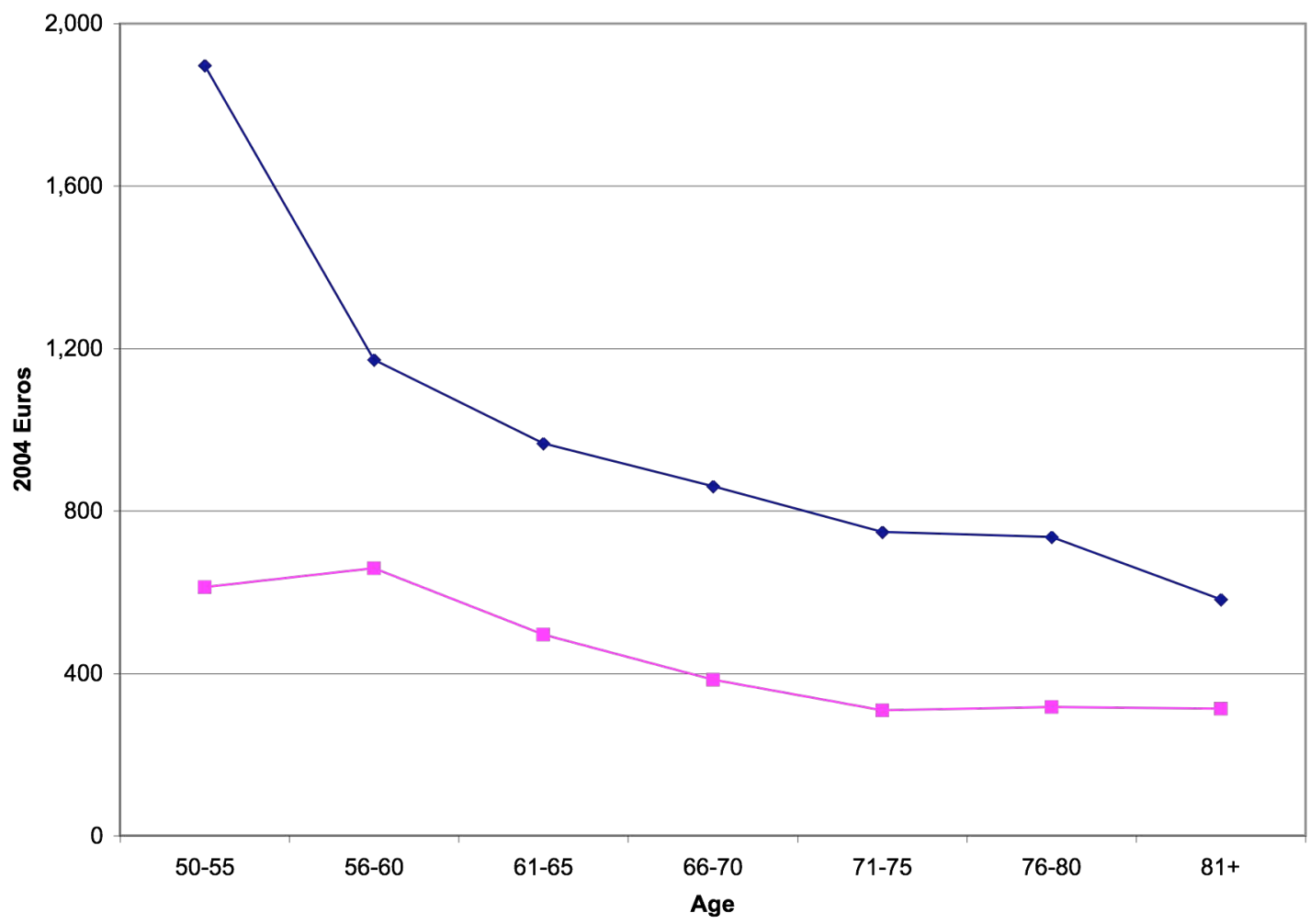

Source: 2004 SHARE Release 2.3.0 and 2004 HRS

Notes: Amounts in 2004 Euros trimmed above $98^{\text {th }}$ percentile. Weighted Results. 
Figure 2. Amount of Money Given to Children by Parent Wealth Quartile for 12 Countries

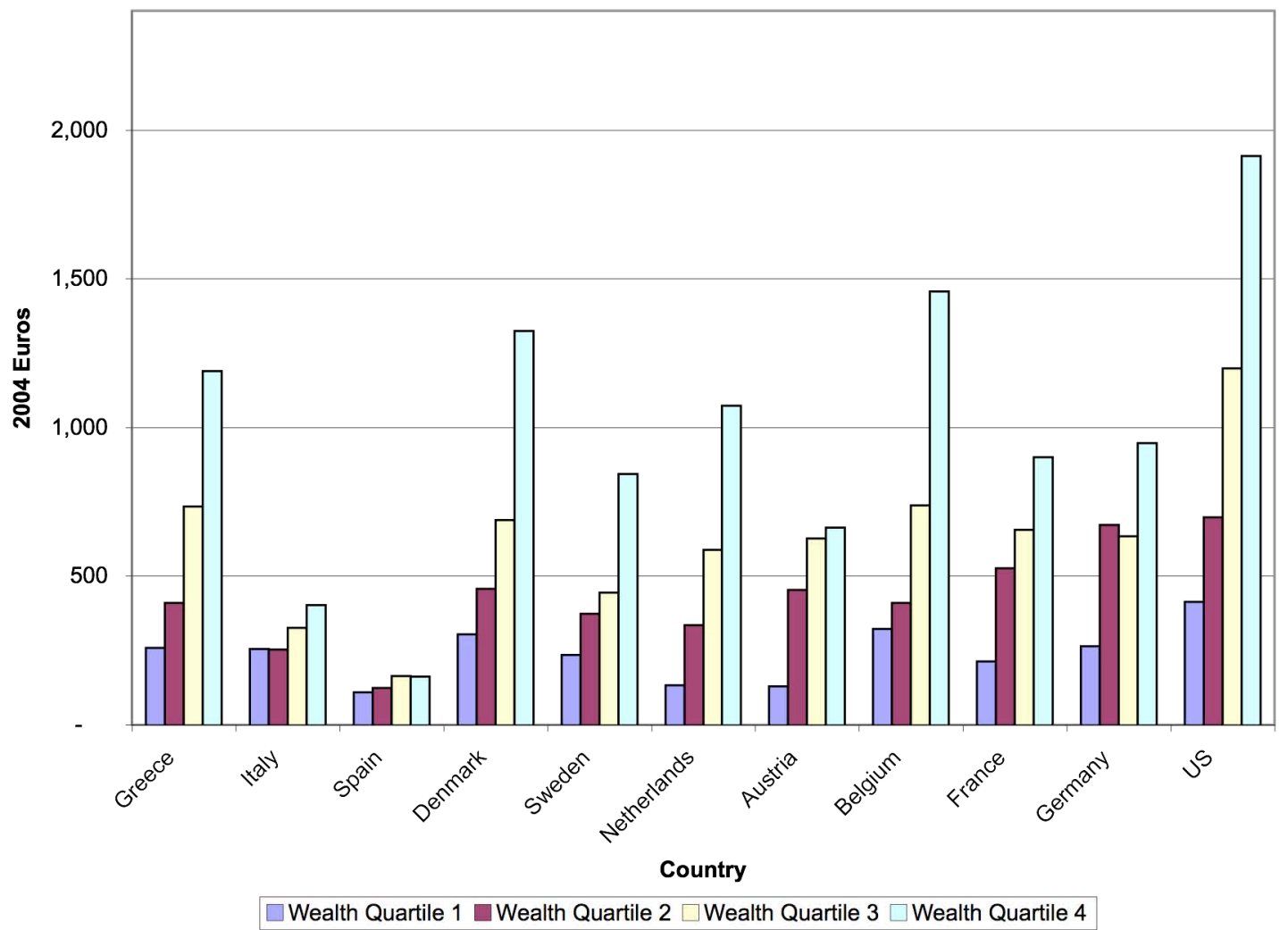

Source: Source: 2004 SHARE Release 2.3.0 and 2004 HRS

Notes: Amounts in 2004 Euros trimmed above $98^{\text {th }}$ percentile. Weighted Results. 
Figure 3. Money Given to All Children in the U.S.: Ratio of $90^{\text {th }} \& 75^{\text {th }}$ Percentiles to Median and $90^{\text {th }}$ to 75 th

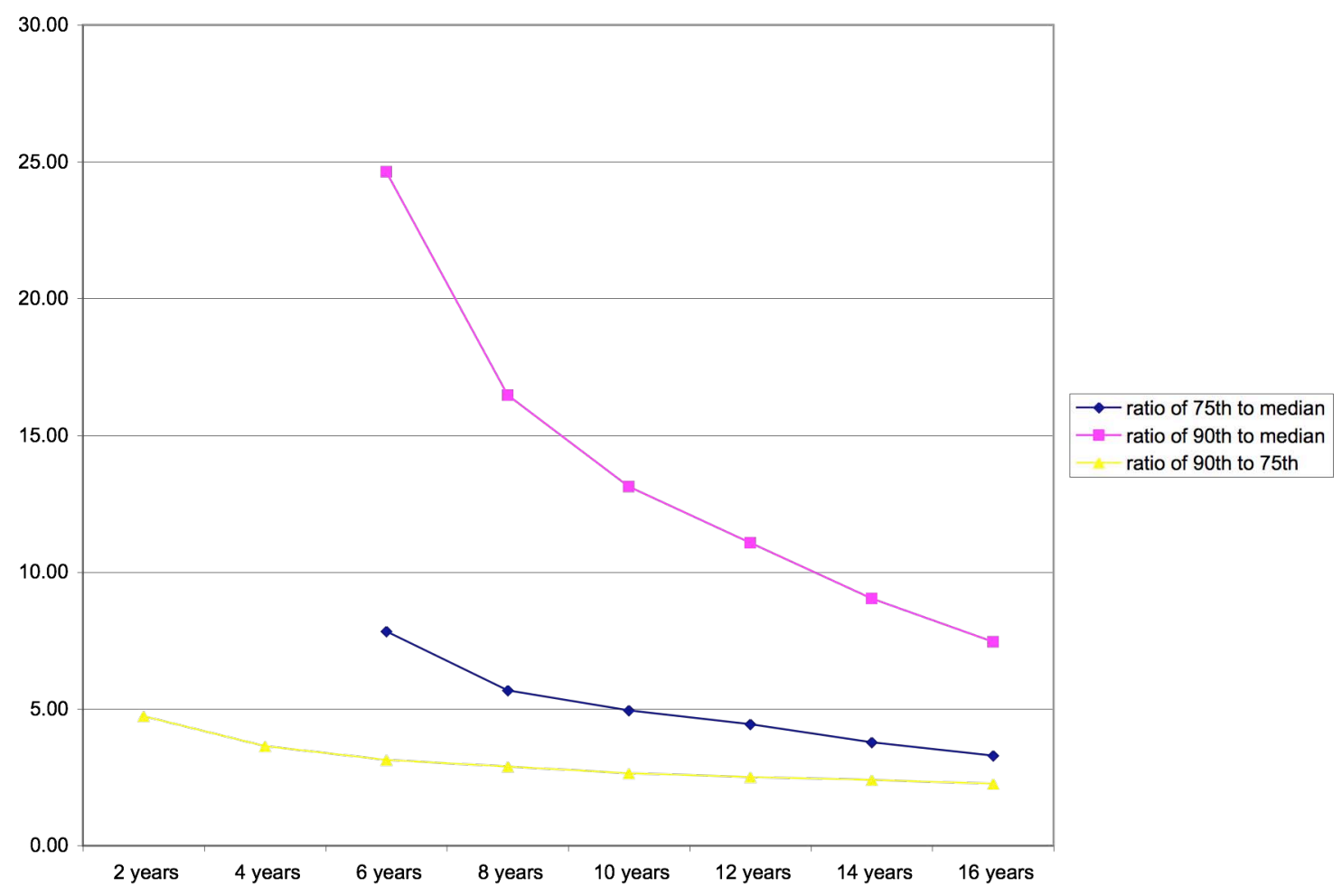

Note: Unconditional Transfer Amounts Based on Table 5a. 
Figure 4a. Within Household Equality of Money Given to Children Over Time in U.S.

Mean of ratio: absolute value of difference in amount of money given to child $i$ in family $j$ and average amount given to all children in family j divided by average amount given to all children

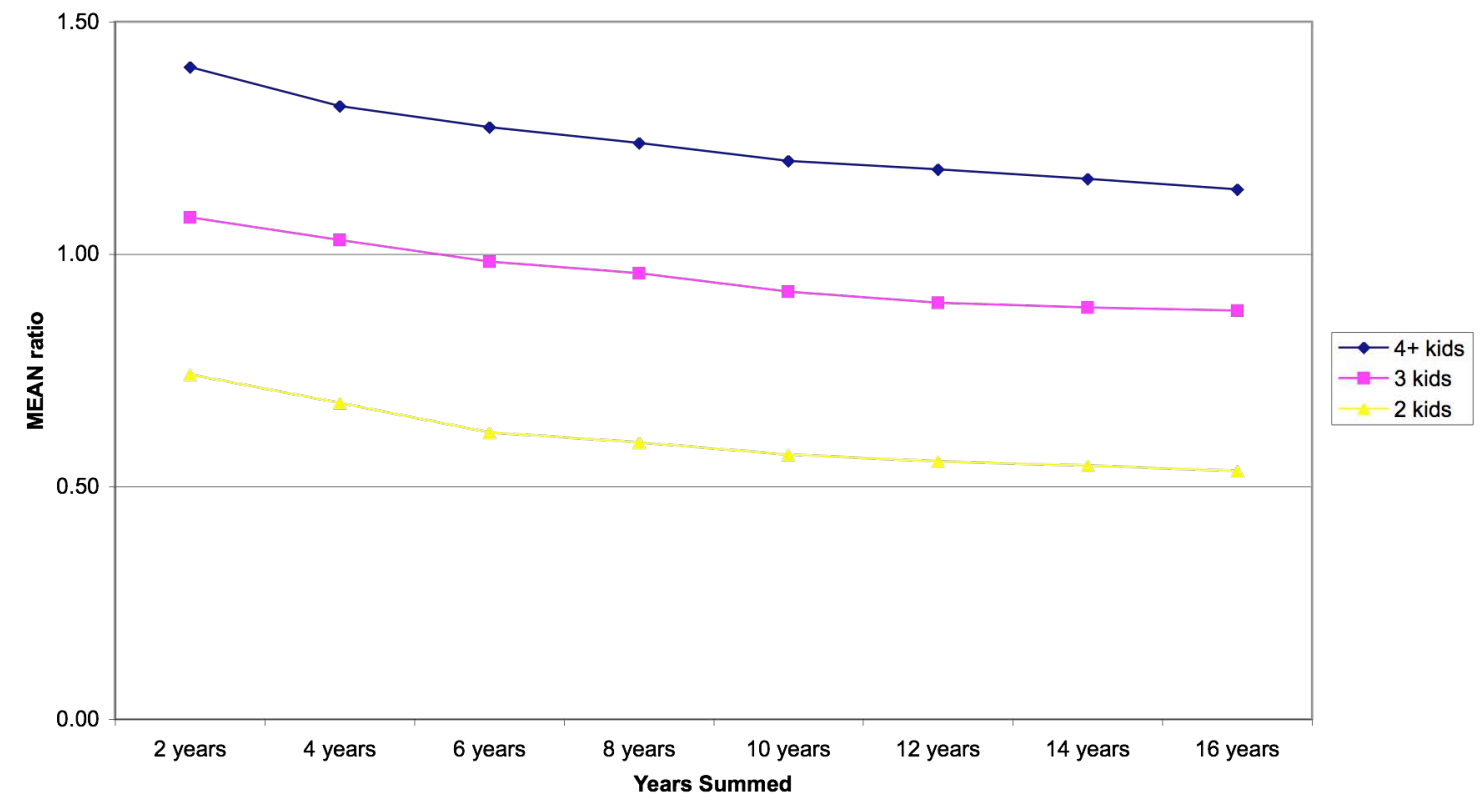


Figure 4b. By Wealth: Within Household Equality of Money Given to Children Over Time in U.S..

Mean of ratio: absolute value of difference in amount of money given to child $\mathrm{i}$ in family $\mathrm{j}$ and average amount given to all children in family j divided by average amount given to all children.

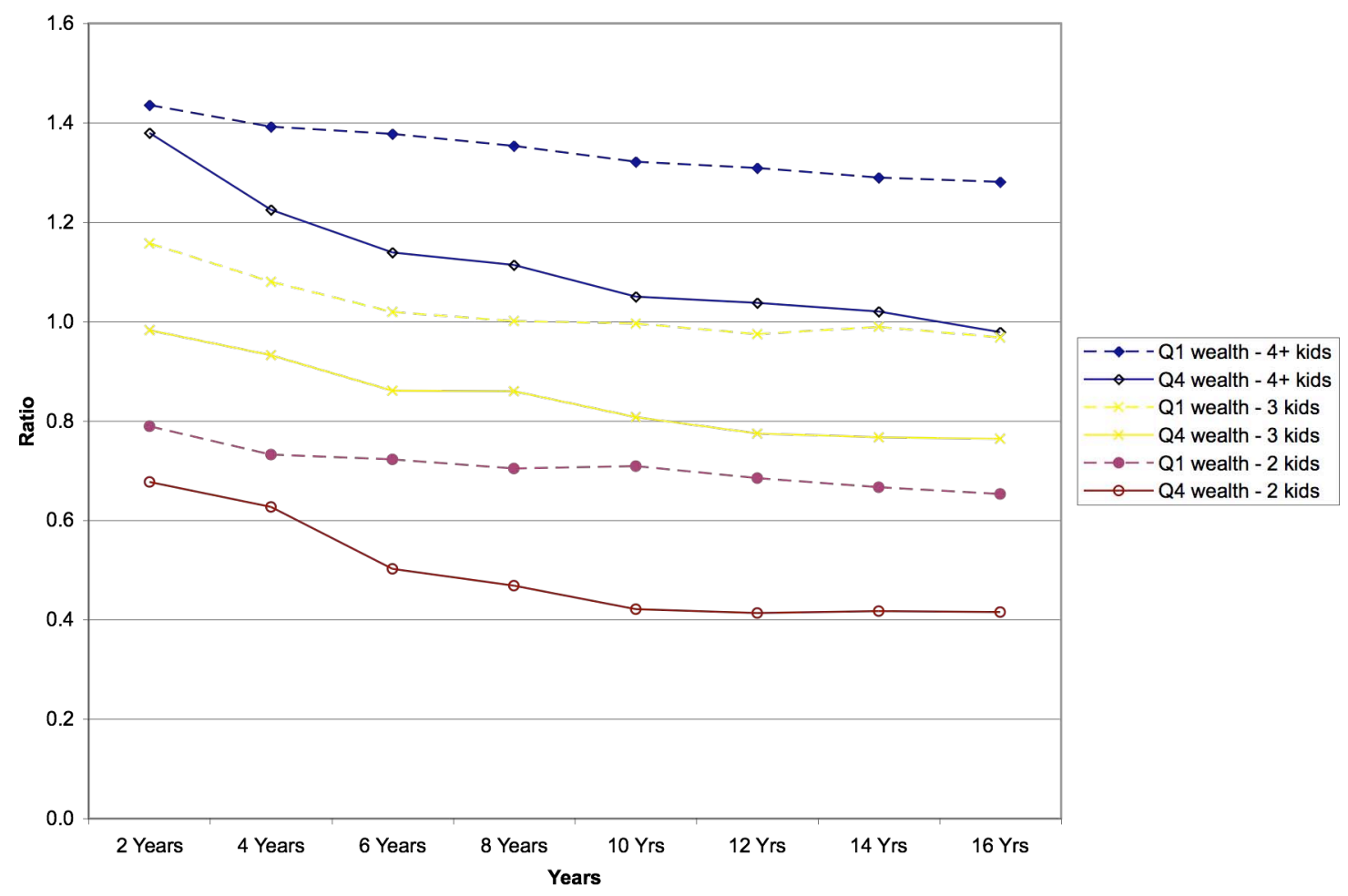


Figure 4c. By Income: Within Household Equality of Money Given to Children Over Time in U.S.. Mean of ratio: absolute value of difference in amount of money given to child $\mathrm{i}$ in family $\mathrm{j}$ and average amount given to all children in family $\mathrm{j}$ divided by average amount given to all children.

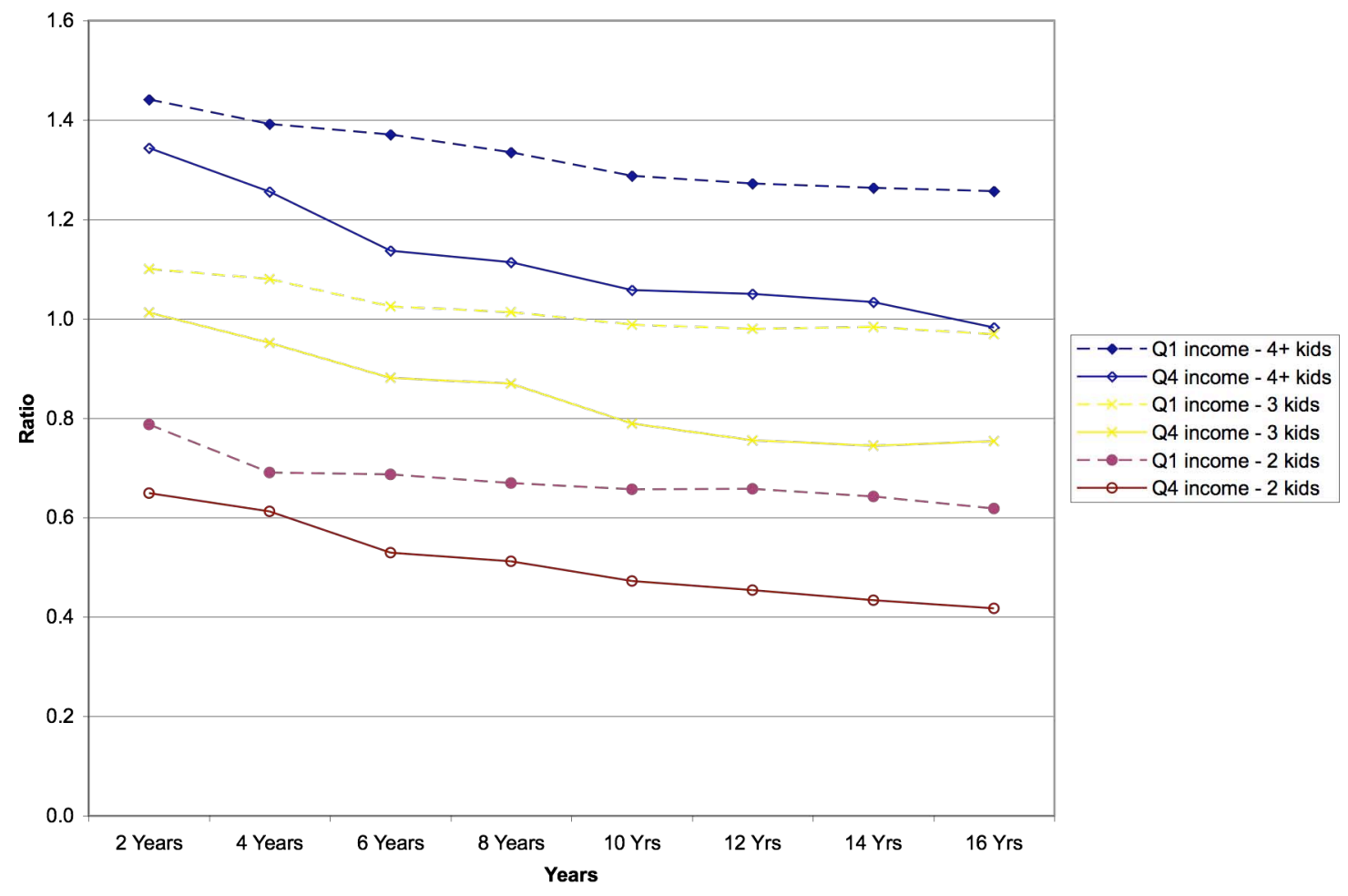


Appendix Table A. Model Results for Money Parents Give a Child Over 2, 8 and 14 Years in the U.S.

\begin{tabular}{|c|c|c|c|c|c|c|}
\hline & \multicolumn{3}{|c|}{ Probability Child Receives Money } & \multicolumn{3}{|c|}{ Amount of Money } \\
\hline & 2 Years & 8 Years & 14 Years & 2 Years & 8 Years & 14 Years \\
\hline Intercept & $0.720 * *$ & $0.909 * *$ & $1.201^{* *}$ & 23,337 & 19,533 & $-36,675$ \\
\hline PARENT CHARACTERISTIC & & & & & & \\
\hline Married & $0.254^{* *}$ & $0.267 *$ & $0.315^{* *}$ & $-9,390$ & $-4,034$ & $59,592 * *$ \\
\hline Male & -0.000 & $0.013 *$ & $0.015^{* *}$ & $-1,208 * *$ & -444 & $-1,474$ \\
\hline Respondent age & -0.004 & $-0.008 *$ & $-0.010 * *$ & 77 & 351 & $2,606 * *$ \\
\hline Respondent age squared & 0.000 & $0.000^{* *}$ & $0.000^{* *}$ & 0 & -2 & $-24 * *$ \\
\hline Spouse age & $-0.009 * *$ & $-0.010 * *$ & $-0.011 * *$ & 321 & -21 & $-2,536 * *$ \\
\hline Spouse age squared & $0.000^{* *}$ & $0.000^{* *}$ & $0.000^{* *}$ & -3 & 1 & $25^{* *}$ \\
\hline R Less than High School & $-0.017 * *$ & $-0.045^{* *}$ & $-0.066 * *$ & -508 & $-1,377$ & $-1,996$ \\
\hline R Some College & $0.020^{* *}$ & $0.053^{* *}$ & $0.052^{* *}$ & -149 & $-1,576^{*}$ & $-4,000 * *$ \\
\hline R College & $0.044^{* *}$ & $0.064^{* *}$ & $0.050 * *$ & 394 & $2,050 * *$ & 690 \\
\hline S Less than High School & $-0.013^{*}$ & $-0.039 * *$ & $-0.047 * *$ & $2,049 * *$ & 717 & 320 \\
\hline S Some College & -0.007 & 0.002 & 0.003 & 148 & 59 & 273 \\
\hline S College & $0.027^{* *}$ & $0.026^{* *}$ & $0.022 *$ & $1,522 *$ & $3,523 * *$ & $9,534 * *$ \\
\hline 2 to 4 kids & $-0.159 * *$ & $-0.197 * *$ & $-0.196 * *$ & $-1,381$ & $-8,773 * *$ & $-9,823 * *$ \\
\hline 5 or more kids & $-0.226 * *$ & $-0.321 * *$ & $-0.338 * *$ & $-2,327 * *$ & $-11,767 * *$ & $-14,879 * *$ \\
\hline Wealth lowest quartile & $-0.052 * *$ & $-0.127 * *$ & $-0.138 * *$ & $-2,196 * *$ & $-2,925 * *$ & $-3,367 *$ \\
\hline Wealth 2nd quartile & $-0.023^{* *}$ & $-0.049 * *$ & $-0.051^{* *}$ & $-1,445^{*}$ & $-1,411^{*}$ & $-1,381$ \\
\hline Wealth top quartile & $0.037 * *$ & $0.081 * *$ & $0.097 * *$ & $2,171^{* *}$ & $7,879 * *$ & $14,600 * *$ \\
\hline Income lowest quartile & $-0.079 * *$ & $-0.129 * *$ & $-0.147 * *$ & -165 & $-3,201 * *$ & $-6,488 * *$ \\
\hline Income 2nd quartile & $-0.041 * *$ & $-0.062 * *$ & $-0.060 * *$ & -998 & $-1,373^{*}$ & $-3,073 *$ \\
\hline Income top quartile & $0.055 * *$ & $0.059 * *$ & $0.054 * *$ & $2,578 * *$ & $5,687 * *$ & $11,657 * *$ \\
\hline CHILD CHARACTERISTIC & & & & & & \\
\hline Kid is step kid & $-0.060 * *$ & $-0.131 * *$ & $-0.146^{* *}$ & $-1,528$ & $-3,146 * *$ & $-8,544 * *$ \\
\hline Kid age & -0.004 & $0.011^{*}$ & -0.002 & $-1,455^{*}$ & -688 & 570 \\
\hline Kid age squared & -0.000 & $-0.001 * *$ & -0.000 & 36 & 10 & -53 \\
\hline Male & 0.001 & -0.005 & -0.006 & -65 & 5 & -772 \\
\hline Coupled & $-0.016^{* *}$ & $-0.040 * *$ & $-0.045^{* *}$ & 529 & -189 & -426 \\
\hline Work part time & $0.042 * *$ & $0.049 * *$ & $0.038 * *$ & -93 & 509 & 979 \\
\hline Work full time & -0.006 & -0.002 & -0.003 & $-1,890 * *$ & $-1,549 *$ & $-1,384$ \\
\hline In school & $0.069 * *$ & $0.058^{* *}$ & $0.058 * *$ & $-1,744$ & $4,200 *$ & 2,980 \\
\hline Less than High School & -0.012 & -0.014 & $-0.022 *$ & $-1,462$ & -453 & 455 \\
\hline Some College & 0.008 & $0.021^{* *}$ & $0.024^{* *}$ & 139 & 531 & -386 \\
\hline College & 0.010 & 0.003 & -0.000 & $1,583^{*}$ & $1,463 *$ & $3,005^{*}$ \\
\hline In school*less HS & -0.034 & 0.006 & -0.006 & 3,253 & $-2,799$ & $-3,190$ \\
\hline In school*some college & $0.123^{* *}$ & $0.070^{* *}$ & 0.026 & $6,176^{* *}$ & 4,033* & $8,307^{*}$ \\
\hline In school*college & $0.077 * *$ & 0.037 & 0.003 & $3,729 *$ & -657 & 1,367 \\
\hline Own home & $-0.021 * *$ & $-0.060 * *$ & $-0.055^{* *}$ & $2,331 * *$ & 1,367 & 1,360 \\
\hline New home & 0.018 & $0.041^{*}$ & 0.023 & 157 & -894 & $-2,408$ \\
\hline Same home & $-0.029 * *$ & -0.020 & $-0.027 *$ & $-1,105$ & 43 & $-2,540$ \\
\hline Lose home & 0.005 & 0.022 & 0.025 & $4,362 *$ & 1,373 & 2,765 \\
\hline 1 to 3 kids & $0.022^{* *}$ & $0.055^{* *}$ & $0.067 * *$ & -862 & 468 & 2,616 \\
\hline 4 or more kids & $0.049 * *$ & $0.072 * *$ & $0.075^{* *}$ & 318 & 501 & 2,267 \\
\hline Co-resides with parent & 0.006 & $0.068^{* *}$ & $0.085^{* *}$ & $1,405^{*}$ & $2,192 * *$ & 3,180 \\
\hline Lives close to parent & $0.017 * *$ & $0.035^{* *}$ & $0.048^{* *}$ & 539 & $1,613^{* *}$ & 1,455 \\
\hline Income - 2nd quartile & $-0.024 * *$ & $-0.016 *$ & -0.002 & -343 & -957 & -526 \\
\hline Income - 3rd quartile & $-0.079 * *$ & $-0.064 * *$ & $-0.037 * *$ & -256 & $-2,378 * *$ & $-2,849$ \\
\hline Income - top quartile & $-0.101^{* *}$ & $-0.099 * *$ & $-0.073 * *$ & -189 & $-1,619$ & $-1,168$ \\
\hline
\end{tabular}

Source: HRS 1992-2006 Sample of respondents present in 7 waves

Notes: All Covariates measured at baseline. Model includes missing and cohort indicators. All amounts CPI adjusted (transfers, income, wealth, earnings). * significant at 5\%; ** significant at $1 \%$ 
Appendix Table B. Descriptive statistics of U.S. sample for regression model

\begin{tabular}{lr} 
Variable & Mean \\
\hline PARENT COVARIATES & 0.75 \\
\hline Married & 0.41 \\
Male & 59.33 \\
Respondent age & 44.00 \\
Spouse age & 0.34 \\
R Less than High School & 0.18 \\
R Some College & 0.14 \\
R College & 0.22 \\
S Less than High School & 0.13 \\
S Some College & 0.12 \\
S College & 0.55 \\
2 to 4 kids & 0.42 \\
5 or more kids & 61,169 \\
Household income (mean) & 284,124 \\
Household wealth (mean) & \\
\hline CHILD COVARIATES & 0.11 \\
\hline Kid is step kid & 32.28 \\
Kid age & 0.51 \\
Male & 0.55 \\
Married & 0.10 \\
Work part time & 0.68 \\
Work full time & 0.09 \\
In school & 0.12 \\
Less than High School & 0.21 \\
Some College & 0.24 \\
College & 0.005 \\
In school*less HS & 0.04 \\
In school*some college & 0.02 \\
In school*college & 0.44 \\
Own home & 0.03 \\
New home & 0.14 \\
Same home & 0.01 \\
Lose home & 0.53 \\
1 to 3 kids & 0.06 \\
4 or more kids & 0.15 \\
Co-resides with parent & 0.27 \\
Lives close to parent & \\
Earnings/Income & \\
\hline SOrC: & \\
\hline
\end{tabular}

Source: HRS waves 1992 to 2006. 
Appendix Table C. College Costs in 2005

\begin{tabular}{lrrr} 
& Private & Public & Both \\
\cline { 2 - 4 } \% of enrolled population & 0.232 & 0.768 & 1.00 \\
Tuition & 21,235 & 5,491 & 9,144 \\
Tuition + room \& board & 29,026 & 12,127 & 16,048 \\
Financial Aid & 9,600 & 3,300 & 4,762 \\
Tuition + R\&B less aid & 19,426 & 8,827 & 11,286 \\
\hline Parental annual transfer & & & 4,608 \\
\hline
\end{tabular}

Source: “Trends in College Pricing 2005,” College Board

${ }^{1}$ 2005-2007 American Community Survey, U.S. Census Bureau 